\title{
The World Distribution of Household Wealth
}

James B. Davies*, Susanna Sandstrom ${ }^{\dagger}$, Anthony Shorrocks ${ }^{\dagger}$, and Edward N. Wolff ${ }^{\ddagger}$

5 December 2006

* Department of Economics

University of Western Ontario

London, Canada N6A 5C2

${ }^{\dagger}$ UNU-WIDER

Katajanokanlaituri 6 B

00160 Helsinki, Finland

${ }^{\ddagger}$ Department of Economics

269 Mercer Street, Room 700

New York University

New York, NY 10003 USA

We thank participants at the May 2006 WIDER project meeting on Personal Assets from a Global Perspective for their valuable comments and suggestions. Special thanks are due to Tony Atkinson and Markus Jäntti. Responsibility for all errors or omissions is our own. 
Much attention has recently been focused on estimates of the world distribution of income (Bourguignon and Morrison, 2002; Milanovic, 2002 and 2005). The research shows that the global distribution of income is very unequal and the inequality has not been falling over time. In some regions poverty and income inequality have become much worse. Interest naturally turns to the question of global inequality in other dimensions of economic status, resources or wellbeing. One of the most important of these measures is household wealth.

In everyday conversation the term 'wealth' often signifies little more than 'money income'. On other occasions economists interpret the term broadly and define wealth to be the value of all household resources, both human and non-human, over which people have command. Here, the term is used in its long-established sense of net worth: the value of physical and financial assets less liabilities. ${ }^{1}$ Wealth in this sense represents the ownership of capital. While only one part of personal resources, capital is widely believed to have a disproportionate impact on household wellbeing and economic success, and more broadly on economic development and growth.

Wealth has been studied carefully at the national level since the late nineteenth or early twentieth centuries in a small number of countries, for example Sweden, the UK and the US. In some other countries, for example Canada, it has been studied systematically since the 1950s. And in recent years the number of countries with wealth data has been increasing fairly quickly. The largest and most prosperous OECD countries all have wealth data based on household surveys, tax data or national balance sheets. Repeated wealth surveys are today also available for the two largest developing countries - China and India, and a survey that inquired about wealth is available for Indonesia. Forbes magazine enumerates the world's US\$ billionaires and their holdings. More detailed lists are provided regionally by other publications, and Merrill-Lynch estimate the number and holdings of US\$ millionaires around the world. National wealth has been estimated

\footnotetext{
1 In some work attempts have been made to include 'social security wealth', that is the present value of expected net benefits from public pension plans in household wealth. We exclude social security wealth here, in part because estimates are available for only a few countries.
} 
for a large number of countries by the World Bank. ${ }^{2}$ In short, there is now an impressive amount of information on wealth holdings. We believe the time has therefore come to estimate the world distribution of household wealth. 3

In this paper we show, first, that there are very large intra-country differences in the level of household wealth. The US is the richest country, with mean wealth estimated at $\$ 144,000$ per person in the year 2000.4 At the opposite extreme among countries with wealth data, we have India with per capita wealth of about $\$ 6,500$ in purchasing power parity (PPP) terms. Other countries show a wide range of values. Even among high income OECD countries there is a range from figures of $\$ 56,000$ for New Zealand and $\$ 66,000$ for Denmark to $\$ 129,000$ for the UK (again in PPP terms).

We also look at international differences in the composition of wealth. There are some regularities but also country-specific differences - such as the strong preference for liquid savings in a few countries, such as Japan. Real assets, particularly land and farm assets, are more important in less developed countries. This reflects not only the greater importance of agriculture, but a lack of financial development that is being corrected in some of the most rapidly growing LDCs. Among rich countries, financial assets and share-holding tend to bulk largest in those with more reliance on private pensions and/or the most highly developed financial markets, such as the UK and US

The concentration of wealth within countries is high. Typical Gini coefficients in wealth data lie in the range of about $0.65-0.75$, while some range above 0.8 . In contrast, the mid-range for

\footnotetext{
2 See World Bank (2005). National wealth differs from household wealth in including the wealth of all other sectors, of which corporations, government and the rest-of-the-world are important examples.

3 One sign of the growing maturity of household wealth data is the launching of the Luxembourg Wealth Study (LWS) parallel to the long-running Luxembourg Income Study (LIS). See http://www.lisproject.org/lws.htm. In its first phase the LWS aims to provide comparable wealth data for nine OECD countries, with the cooperation of national statistical agencies or central banks. The LWS initiative differs from ours in that its aim is not to estimate the world distribution of wealth, but to assemble fully comparable wealth data across an important subset of the world's countries.

4 All our wealth estimates are for the year 2000. Wealth data typically become available with a significant lag, and wealth surveys are conducted at intervals of three or more years. The year 2000 provides us with a reasonably recent date and good data availability.
} 
income Ginis is from about $0.35-0.45$. The mid value for the share of the top 10 per cent of wealth-holders in our data is 50 per cent, again higher than is usual for income.

While inter-country differences are interesting, our goal is to estimate the world distribution of wealth. In order to do so we need estimates of the levels and distribution of wealth in countries where data on wealth are not available. Fortunately for our exercise, the countries for which we have data included 56 per cent of the world's population in the year 2000 and, we estimate, more than 80 per cent of its household wealth. Careful study of the determinants of wealth levels and distribution in the countries that have wealth data allows imputations to be made for the 'missing countries'.

The remainder of the paper is organized as follows. In the next section we study what can be learned about household wealth levels and composition across countries using household balance sheet and survey data. Section 3 presents our empirical results on the determinants of wealth levels, and imputes household wealth totals to the 'missing countries'. Section 4 reviews evidence on the distribution of wealth where available, and then performs imputations for other countries. In Section 5 levels and distributions are combined to construct the global distribution of household wealth. Conclusions are drawn in Section 6.

\section{Wealth Levels}

Our objective in this section is to develop data on measured wealth levels in as many countries as possible. These data are of independent interest, but are also used in the next section to impute per capita wealth to a large sample of countries that do not have wealth data. The exercise begins by taking inventories of household balance sheet (HBS) and sample survey estimates of household wealth levels and composition. Sources and Methods for HBS data are detailed in Appendix I, and sources of survey data are shown in Appendix III.

\section{A Household Balance Sheet (HBS) Data}

We have assembled balance sheets for as many countries as possible. As indicated in Table 1, 'complete' financial and non-financial data are available for 18 countries. These are all high income countries, except for the Czech Republic, Poland, and South Africa, which are upper 
middle income countries.according to the World Bank classification. 5 We considered the data complete if there was full or almost full coverage of financial assets, and inclusion at least of owner-occupied housing on the non-financial side. There are 15 other countries that have comparable financial balance sheets, but no information on the real side. Here there is better representation outside the high income countries, with six upper middle income countries and three lower middle income.

Country coverage in HBS data is not representative of the world as a whole. Such data tend to be developed at a relatively late stage in the development of national economic statistics. Europe and North America, and the OECD in general, are well covered, but low income and transition countries are not. 6 In geographic terms this means that coverage is sparse in Africa, Asia, Latin America and the Caribbean. Fortunately for this study, these gaps in HBS data are offset to an important extent by the availability of survey evidence for the largest developing countries, China, India and Indonesia, as discussed below. Also note that while there are no HBS data for Russia, we do have complete HBS data for two European transition countries and financial data for eight others.

Table 2 summarizes key characteristics of the household balance sheet data by country. As discussed in Appendix I, methods and sources differ across countries. This is especially true for non-financial assets. Often, the balance sheets are compiled in conjunction with the National Accounts or Flow of Funds data, but there are several exceptions. For countries such as New Zealand, Portugal and Spain, data are reported by central banks and include estimates based on Financial Accounts augmented with data on housing assets. The German and Italian data are to a large extent also based on central bank data but are more complete. The German data are based on Financial Accounts data from Deutsche Bundesbank and non-financial assets data including

\footnotetext{
5 We used the World Bank classification throughout the paper except that Brazil, Russia and South Africa were moved from the lower middle income category to higher middle income, and Equatorial Guinea from low to lower middle income. We made these changes since the WB classifications seemed anomalous on the basis of the Penn World Table GDP data that we use for year 2000.

6 Goldsmith (1985) prepared 'planetary' balance sheets for 1950 and 1978 and found similar difficulties in obtaining representative coverage. He was able to include 15 developed market economies, two developing countries (India and Mexico), and the Soviet Union. This produces a total of 18 countries, equal in number to the countries for which we have complete HBS data for the year 2000.
} 
housing assets, other real assets and durables. The Italian data are based on the Financial Accounts from the Bank of Italy augmented with Italian statistical office (Istat) estimates of the stock of dwellings and calculations of durable goods based on Istat data by Brandolini et. al (2004). Even if the household balance sheets are based on data from the national statistical organizations they do not necessarily have a broad coverage of non-financial assets. The data for the Netherlands are a mix of data from Statistics Netherlands and the central bank, and the financial balance sheets are only augmented with data on owner-occupied housing. The nonfinancial data from the Singapore Department of Statistics also covers only housing assets. For Denmark we combined financial balance sheet data with fixed capital stock accounts reported by Statistics Denmark.

Summarizing, each of the 18 countries we have classed as having complete balance sheets have good financial data plus some information on housing. Poland, Singapore and the Netherlands are at this minimum level. Fifteen countries report data on some other real property, including land and/or investment real estate in most cases, and six have estimates for consumer durables.

We considered whether we could make imputations that would make the non-financial coverage in these 'complete' balance sheets more uniform. We found that it would be very difficult to do a satisfactory imputation for land or investment real estate. ${ }^{7}$ We have therefore not imputed these items. Since only three countries are completely missing these items and eight countries, including the US have complete data, we believe that while gaps for these items do have some effect on our results, the impact should not be exaggerated. In contrast, it is possible to do a reasonable imputation for consumer durables. Since this improves estimates for twelve countries, we included these imputations. 8

\footnotetext{
7 While the value of land occupied by included dwellings is captured in the balance sheets, other land is missing for Denmark, Germany, Italy, the Netherlands, and Singapore. Investment or commercial real estate is missing for the Netherlands, New Zealand, Portugal and Singapore, and for Italy (for which all housing is included, whether owner occupied or not, but not other real estate). To the best of our knowledge, in all other cases both land and all real estate owned by households are included in the data specification.

8 Durables data are available for Canada, the US, Germany, Italy and South Africa. We used the mean ratio of durables to GDP in Canada and the US to impute durables to Australia, New Zealand, and the UK. For European countries other than the UK we used the mean ratio for Germany and Italy. Finally, the mean ratio for Canada, the US, Germany and Italy was used to do the imputation for Japan and Singapore.
} 
Table 2 also shows that there are differences in sectoral definition across countries. We aimed for a household sector which covered the assets and debts of households and unincorporated business. However, non-profit organizations (NPOs) are sometimes grouped in with households. We would like to exclude NPOs, and had data allowing us to do so for the UK and US. This correction is especially important for the US where NPOs account for about 6 per cent of the financial assets of the household sector (Board of Governors of the Federal Reserve System, 2003).

Table 3 reports the asset composition of household balance sheets. The asset composition reflects different influences on household behaviour such as market structure, regulation and cultural preferences (IMF, 2005). One needs, however, to be careful when analyzing these data since the comparison may be affected by sectoral definition, asset coverage and methodological differences. For most countries, non-financial assets account for between 40 and 60 per cent of total assets, with higher shares in the Czech Republic, New Zealand, Poland and Spain. Housing assets constitute a considerable share of non-financial assets. In the United Kingdom and some other countries, the large increase in real estate prices in the late 1990's helps to explain a high housing share. The high share of financial assets makes South Africa stand out. One would expect real assets like housing, land, agricultural assets and durables to be important in a developing country, but due to well developed financial markets combined with continuously negative rates of return on investment in fixed property and relatively high mortgage interest rates, the share of non-financial assets is unusually low in South Africa (see Aron et al., 2006). The United States is also an outlier in the share of financial assets, which is clearly related to the strength of its markets, but may also be partly explained by its relatively cheap housing.

Turning to the composition of financial assets, we can draw on the 15 countries for which we have financial balance sheets only, in addition to the 18 with complete balance sheets. There are some striking differences across countries. We disaggregate into liquid assets, shares and equities, and other financial assets. In Japan and most of the European transition countries, liquid 
assets are a large part of the total.9 In transition countries this is expected due to poorly developed financial markets. In Japan the preference for liquidity has a long history but also reflects lack of confidence in real estate and shares after their poor performance in the 1990's (Babeau and Sbano, 2003). In some countries, such as Australia, Austria, the Netherlands, South Africa and the UK the share of other financial assets is particularly high. This may be partly attributable to the importance of pension fund claims in these countries. Italy stands out as having a particularly low share of liabilities, something that is confirmed by survey data (see below).

\section{B Survey data}

In order to check on our HBS data and to expand our sample, especially to non-OECD countries, we also consulted household wealth survey data. Table 4 shows there is more variation in country coverage than in the HBS data. Most importantly, wealth surveys are available for the three most populous developing (and emerging market) countries: China, India and Indonesia. These three countries, together with Finland, and Mexico in the case of non-financial assets, are used in regressions in the next section that provide the basis for wealth level imputations for our 'missing countries'.

Like all household surveys, wealth surveys suffer from sampling and non-sampling errors. These are typically more serious for estimating wealth distribution than e.g. for income distributions. The high skewness of wealth distributions makes sampling error more severe. Non-sampling error is also a greater problem since differential response (wealthier households less likely to respond) and misreporting are generally more important than for income. Both sampling and non-sampling error lead to special difficulties in obtaining an accurate picture of the upper tail, which is of course one of the most interesting parts of the distribution (see Davies and Shorrocks, 2000 and 2005).

\footnotetext{
9 Among the transition countries, shares of liquid assets in total financial assets are 60 per cent or higher for Bulgaria, the Czech Republic, Croatia, Romania, and Slovakia. Estonia and Lithuania stand out as having liquid asset shares of one-third or lower. Latvia, Hungary and Slovenia are intermediate between these extremes.
} 
In order to offset the effects of sampling error in the upper tail, well-designed wealth surveys over-sample wealthier households. This is the practice in the US Survey of Consumer Finances and the Canadian Survey of Financial Security, for example.10 Among the four countries whose survey data are used in the regressions reported in the next section, however, only Finland oversamples rich households. Sampling error may therefore be of some concern in the Chinese CASS survey, the Indian AIDIS survey (part of the Indian National Sample Survey round 59) and the Indonesian Family Life Survey. This is despite very high reported response rates (in excess of 90 per cent) in both China and India. In the case of the Chinese survey, there are additional difficulties regarding the representativeness of the wealth survey sub-sample, which covers only a part of the provinces included in the sample of the State Statistical Bureau Household Income Survey. The SSB sample itself also suffers from some degree of geographical under-coverage (Bramall, 2001). The Indonesia Family Life Survey also has some coverage limitations. The survey is reported to be representative of 83 per cent of the Indonesian population covering 13 of the nation's 27 provinces.

As mentioned above, non-sampling errors include both differential response by wealth level and misreporting (mostly under-reporting). Wealthy households are less likely to respond to surveys. As found here, comparisons with HBS data generally show lower totals for most financial assets in surveys. This may be due to differential response and/or under-reporting by those who do respond. 11 In contrast, non-financial assets, especially housing, are sometimes better covered in survey data. In terms of asset coverage the Finnish survey concentrates on financial assets, housing and vehicles. The surveys from the three developing countries pay relatively little attention to financial wealth since it is of less importance there, and concentrate on housing, agricultural assets, land and consumer durables. The asset coverage and details of the surveys reflect the relative importance of specific assets in rich and relatively poor countries.

\footnotetext{
10 The SCF design explicitly excludes people in the Forbes 400 list of the wealthiest Americans, which again helps to reduce the effects of sampling error. See Kennickell (2004).

11 Also, certain assets and liabilities in the balance sheets for the household sector are often computed as a residual, after the balance sheets for the government and corporate sector are first computed. The total asset values for the household sector are then given as the difference between total national wealth and the sum of these two other sectors, as in the US Flow of Funds. As a result, balance sheet totals for the household sector are also prone to error.
} 
Table 4 reports asset composition in the survey data. It is clear that non-financial assets bulk larger in surveys than in HBS data, reflecting both the relative accuracy of housing values in survey data and the importance of under-reporting and non-response among rich households, who own a disproportionate share of financial assets. The table also shows how different is the importance of non-financial and financial assets in developed and developing countries. The two low income countries in our sample, India and Indonesia, stand out as having particularly high shares of non-financial wealth.12 This is no surprise since assets such as housing, land, agricultural assets and consumer durables are particularly important in many developing countries. In addition, financial markets are often poorly developed. In India, the only low or middle income country for which we have some detail on financial assets, most of the financial assets owned by households are liquid. Renwei and Sing (2005) report more detailed data for urban areas of China, showing that about 64 per cent of household financial assets there are liquid. In our table, China does not stand out as having high shares of non-financial assets. One reason is that the value of housing is reported net of mortgage debt in China. Another is that there is no private ownership of urban land. In addition, according to Renwei and Sing (2005), there has been a rapid increase of financial assets especially in rural areas, reflecting the deepening of market oriented reforms.

The ratio of liabilities to total assets is particularly low in India and Indonesia (for China only non-housing liabilities are reported). Again poorly developed financial markets help to explain this phenomenon. But, in addition, underreporting of debt appears to be more severe than underreporting of assets. Subramanian and Jayaraj (2006) estimate that debts are, on average, underrepresented by a factor of 2.93 in the AIDIS. Italy also stands out as having a very low share of liabilities. This low share echoes the finding in HBS data, and likely reflects a real difference between Italy and other high income OECD countries.

\footnotetext{
12 This echoes the findings of Goldsmith (1985) who reported that India and Mexico had an average of 65.0 per cent of national assets in tangible form in 1978, vs. 50.8 per cent for fourteen developed market economies.
} 


\section{Per Capita Wealth from Household Balance Sheet and Survey Data}

Table 5 summarizes the distribution of per capita wealth in the year 2000 among countries for which we have complete household balance sheet and/or wealth survey data. (Data for individual countries are given in Appendix IV.) The data are given both on PPP and official exchange rate bases.

Of the 18 countries for which we have complete HBS data, the US ranks first on a PPP basis (although it is surpassed by Japan at official exchange rates), with per capita wealth of $\$ 143,727$ in 2000 , followed by the UK at $\$ 126,832$, Japan at $\$ 124,858$, the Netherlands at $\$ 120,086$, Italy at $\$ 119,704$, and then Singapore at $\$ 113,631$. South Africa is last, at $\$ 16,266$, preceded by Poland at \$24,654 and the Czech Republic at \$32,431. The overall range is rather large, with per capita wealth in the US 8.8 times as great as that of South Africa on the PPP basis. Differences are even greater on an exchange rate basis, with the US/South Africa ratio rising to 24.0. The coefficient of variation (CV), among the 18 countries rises from 0.427 on a PPP basis to 0.594 on the exchange rate basis.

The next column shows GDP per capita. In the group of 18 countries with HBS data, the US again ranks first, at $\$ 35,619$, and South Africa last, at $\$ 8,017$ on a PPP basis. However, the range is much smaller than for net worth per capita. The ratio of highest to lowest GDP per capita is only 4.4, and the (unweighted) coefficient of variation of GDP per capita (again among the 18 countries) is 0.311 , compared to 0.427 for net worth per capita. On the exchange rate basis the CV of GDP per capita is 0.519 , compared to the 0.594 figure for wealth. These results are a first illustration of the fact that, globally, wealth is more unequally distributed than income. The comparison here is only between countries. The full results we present later in the paper include inequality within countries, which further increases the gap between income and wealth inequality.

In column 4 we show personal disposable income per capita for the same group of countries. The US again ranks first, at $\$ 25,480$, South Africa is again last, at $\$ 4,691$ on a PPP basis, and the ratio of highest to lowest is 5.4, slightly higher than for GDP per capita. The coefficient of variation is 0.326 , again slightly higher than that of GDP per capita. The last column shows real consumption per capita. Once again, the US ranks first and South Africa last, the ratio of highest 
to lowest on a PPP basis is 4.7, about the same as GDP per capita and slightly higher than that of disposable income per capita. The CV is 0.319, slightly higher than that of GDP per capita and slightly lower than that of disposable income per capita. On the exchange rate basis inequality between countries is again greater than on a PPP basis. All in all, the variation of net worth per capita is much greater than GDP per capita, disposable income per capita, and consumption per capita.

The difference between countries is even more pronounced in the survey data results than in the HBS data, due to the inclusion of three developing countries (China, India and Indonesia). Of the 13 countries for which we have the pertinent data, the US again ranks first in net worth per capita, at $\$ 143,857$, followed on a PPP basis by Australia at $\$ 101,597$, and Japan at $\$ 91,856$. In this group, India is last, at $\$ 6,513$ on a PPP basis and $\$ 1,112$ on an exchange rate basis, preceded by Indonesia, at $\$ 7,973$ on a PPP basis and $\$ 1,440$ using official exchange rates. China appears to be about twice as wealthy as India, having per capita net worth of $\$ 11,267$ on a PPP basis or $\$ 2,613$ using official exchange rates.

In the survey data, as in the HBS data, the range in per capita wealth is much larger than that of per capita GDP, disposable income, or consumption. The ratio of highest to lowest is 22.1 for net worth per capita, 13.3 for both GDP and disposable income, and 17.3 for consumption on a PPP basis. Again, the coefficients of variation for the income and consumption variables are smaller than for wealth, and inequality is considerably greater using official exchange rates rather than PPP.

Wealth per capita is closely related to both income per capita and consumption per capita. The correlation between net worth and GDP is only 0.739 in the HBS data on a PPP basis, but that correlation rises to 0.848 on an official exchange rate basis, and is higher again in the survey data - at 0.908 on an exchange rate basis (see Table 6). Correlations of wealth and disposable income are higher from both HBS and survey sources — rising to 0.958 in the survey data on an exchange rate basis. Correlations of wealth with consumption are a little lower: 0.860 from balance sheet data and 0.922 from survey data, again on an exchange rate basis. The highest correlations are between the logarithm of net worth per capita and the logarithm of disposable income per capita: 0.975 from the balance sheet data and 0.993 from the survey data using 
official exchange rates. Correlations of the logarithm of net worth per capita and the logarithm of consumption per capita are slightly lower.

\section{Imputing per Capita Wealth to other Countries}

We next impute per capita wealth to the remaining countries of the world. For a large number of countries part or all of wealth is imputed on the basis of regressions run on the 38 countries for which we have HBS or survey data, as detailed below. This gives us 150 countries with observed and/or imputed wealth, covering 95.2 per cent of the world's population in 2000. It is tempting to regard the results as representing the global picture. However this would implicitly assume that the 79 excluded countries and people are neither disproportionately rich or poor. This assumption is untenable. While the omitted countries include several smaller rich nations (for example, Liechtenstein, the Channel Islands, Kuwait, Bermuda), the most populous countries (Afghanistan, Angola, Cuba, Iraq, North Korea, Myanmar, Nepal, Serbia, Sudan and Uzbekistan each have more than 10 million population) are all classified as low income or lower middle income. To try to compensate for this bias, to each of the omitted countries we assign the mean per capita wealth of the continental region (6 categories) and income class (4 categories). 13 This assumption is admittedly crude, but nevertheless an improvement over the default of simply disregarding the excluded countries. It allows us, in the end, to assign wealth levels to 229 countries.

The regressions we report below are designed to help us predict wealth in countries where wealth data are missing. The goal is not to estimate a structural model of wealth-holding, but to find equations that fit well in-sample and that will also allow us to predict out-of-sample. The nature of this exercise limits the range of models that can be applied. Perhaps most importantly, it limits our choice of explanatory variables to those that are available not only for the countries with wealth data but also for a large number of countries without wealth data.

13 Middle income Oceania was assigned a simple average of Fiji and New Zealand. 


\section{A Wealth Regressions}

We first experimented with OLS regressions for those countries with complete wealth data, excluding the 16 countries with incomplete data shown in Table 1 . Initially our dependent variable was simply per capita wealth. The principle independent variable was per capita income or consumption. As Figures 1 and 2 make evident, there is a strong relationship between wealth and income, so these equations fit fairly well.14 However, we discovered that we could predict better if we disaggregated wealth into (i) non-financial assets, (ii) financial assets and (iii) liabilities, and ran separate regressions for each. Part of the reason this approach yields better results is that some variables are helpful in predicting one or two of these components, but not all three. Also, the relative impacts of common variables vary across the equations. There are significant gains from the greater flexibility offered by running separate regressions.

Having discovered that the results improved when we ran three regressions, we realized that productive use could be made of data from countries where some, but not all three, components were available. For the 15 countries shown in Table 1 with financial balance sheets, but no data on real assets, there are observations of both financial assets and liabilities. And for Mexico, we have an observation of non-financial assets. Adding observations from these countries has a benefit not only in increasing sample size, but in bringing in more developing and transition countries. The regressions therefore become better at predicting wealth for the 'missing countries'.

For our dependent variables we use the household balance sheet data discussed above for 33 countries, and survey data for five countries that lack HBS data (China, Finland, India, Indonesia, and Mexico). In each regression the income variable is very important. The best fit is obtained using disposable income per capita. We show the results of those runs in Appendix II. Here we highlight runs using real consumption per capita instead, since this variable is available for about twice as many countries as disposable income, which makes the consumption

\footnotetext{
14 Figure 1 uses wealth from the HBS data while Figure 2 uses wealth from survey data. The slopes of the simple regression lines in the two figures are similar, but the intercept is higher with HBS data. This reflects the fact that survey data generally provide lower estimates of wealth than national balance sheets.
} 
specification far more useful for imputations. Using consumption reduces goodness of fit only slightly.

Since errors in our three equations are likely to be correlated we investigated using the seemingly unrelated regressions (SUR) technique due to Zellner (1962).15 This involves stacking the three equations and estimating via generalized least squares. While OLS estimates would be consistent, SUR provides greater efficiency. The gain in efficiency is expected to be greater the more highly correlated are the errors across the equations, and the less correlated are the regressors used in the different equations. For equations with an equal number of observations it is straightforward to apply SUR in STATA. The results we show here for the financial assets and liabilities regressions are therefore performed using SUR.16

Table 7 shows our results with three different versions of the consumption specification, labelled $a$ through $c$. Our preferred specifications are $b$ for non-financial wealth and $c$ for financial wealth and for liabilities. Variable sources are given in Appendix II. Both the dependent variables and most of the independent variables are entered in log form. Note first that real consumption per capita appears significant at the 1 per cent level in all of the runs. The estimated elasticities of non-financial and financial wealth with respect to consumption are 1.028 and 1.177 respectively in our preferred runs. The slightly greater elasticity for financial wealth seems plausible, since higher income countries tend to have better developed financial markets. There is an even larger difference for liabilities, which have an estimated elasticity of 1.487. These differences imply that, for the many low income countries where we make imputations, there will be a tendency coming from the consumption variable for their imputed financial assets and (especially) liabilities to be relatively less important than their non-financial assets.

15 See also Greene, 1993, pp. 486-499.

16 While it is theoretically possible to apply SUR with an unequal number of observations in the equations estimated, this is very difficult to do in STATA or (we expect) in other standard packages. Also, while errors in the financial assets and liabilities equations are likely to be correlated, this is less likely in comparing either of those variables with non-financial assets. Estimates of the latter generally come from different sources and are prepared using different techniques from those used in financial balance sheets. Thus correlations in measurement error, at least, should be small. 
We tried a dummy variable indicating the data source (HBS or survey data) in all three regressions. It was insignificant in the regression for non-financial assets, which is not unexpected since survey data typically cover non-financial assets quite well. While significant at the 10 per cent level in the first liabilities specification, it loses significance in the $b$ specification and was dropped from the final run. In contrast, the survey dummy is significant at the 1 per cent level in all three runs for financial wealth. With a value of -1.516 in the $c$ run, this dummy reflects the well-known fact that financial assets are under-reported and under-represented in survey data.

We also considered five other independent variables:

Population Density: The value of non-financial assets, particularly housing, should be positively related to the degree of population density (greater density indicating a relative scarcity of land). This variable is statistically significant in the non-financial asset regressions. Market Capitalization Rate: The value of household financial assets should be positively correlated with this measure of the size of the stock market. It is positive and significant in all three regressions for financial wealth. This is a useful result in terms of prediction and imputations, since the variable is available for a large number of countries that do not have full wealth data.

Public Spending on Pensions as a Percentage of GDP: We expected this might be negatively related to financial assets per capita, since public pensions may substitute for private saving. However, this variable is not statistically significant and was dropped.

Income Gini: Some theoretical models suggest that income inequality and per capita wealth should be positively related. However, the variable turns out to be insignificant.

Domestic Credits Available to the Private Sector: This variable is highly significant in the liabilities regression, which is fortunate from the imputation perspective since, as in the case of market capitalization, the variable is available for many of our 'missing countries'.

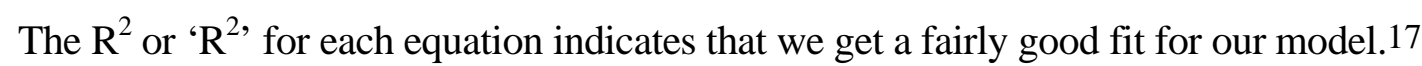

$17 \mathrm{R}^{2}$ is not a well-defined concept in generalized least squares, so as is customary the fraction of the variance in the dependent variable that is 'explained' in each regression is referred to as ' $\mathrm{R}$ ', here. 


\section{B Imputations}

Table 8 shows summary results for our full sample of 229 countries. We again grouped countries into (i) high income OECD; (ii) high income non-OECD; (iii) upper middle income; (iv) lower middle income; and (v) low income classes, and present information here for groups only. A complete list of estimated wealth by country is provided in Appendix V.

Looking first at the 24 high income OECD countries, on a PPP basis we find a share of world household wealth of 63.7 per cent, much larger than this group's 14.8 per cent share of world population and significantly more than its 53.6 per cent share of world GDP. Thus we have an immediate indication of the high concentration of world wealth in the richest countries, and a strong indication that wealth is more unequally distributed across countries than is income. The degree of concentration is even greater if the calculations are done on an official exchange rate basis. The high income OECD countries then have 83.3 per cent of world household wealth (and 76.9 per cent of world GDP); and as we found above for countries with HBS or survey data, the $\mathrm{CV}$ of per capita wealth is much higher when we measure wealth on an exchange rate basis.

While it is natural to compare wealth levels across countries in terms of wealth per capita, other options may also have attractions. In particular, there is a case for expressing wealth levels in terms of the average wealth per family (or household) or the average wealth per adult, the latter reflecting an implicit assumption that the wealth holdings of those under 20 years of age can be neglected in global terms. The choice between the three alternative concepts becomes more significant in the context of wealth distribution, and is discussed in more detail in Section 5 below. Here we simply note that computing average wealth per household poses practical problems, since the total population of households is not reported for many countries. In contrast, the number of adults (specifically, the number of persons aged 20 or above) is widely available. We therefore provide a second set of figures for the average wealth per adult in each country.18

\footnotetext{
18 When the population over 20 is not reported, we imputed estimates based on the average proportion of adults in the region-income category used previously. Imputed levels of wealth per adult use regional averages weighted by the number of adults rather than the total population.
} 
Table 8 shows that for the high income OECD countries wealth per adult is about a third higher than wealth per capita (\$151,308 vs. $\$ 113,675$ in PPP results). Larger proportional differences are found for lower income countries, where adults comprise a smaller fraction of the population. Wealth inequality among these high income OECD countries is higher on a per adult basis than on a per capita basis, but the difference is quite small.

For the high-income non-OECD and upper middle income groups we again find that wealth inequality tends to be greater than income inequality, and that both wealth and income inequality between countries are higher within the group when we use official exchange rates rather than PPP. (There is no systematic difference between wealth inequality on a per adult vs. per capita basis.) However, for the 59 lower middle income and 64 low income countries we find different results. In both cases per capita wealth inequality is less than inequality in per capita GDP according to our estimates. 19 And for the low income countries inequality is greater on a PPP basis than when using official exchange rates (true for both wealth and GDP).

On a PPP basis the 43 countries in the high-income non-OECD group accounted for 3.23 per cent of world household wealth and 2.35 per cent of world GDP, while having just 0.93 per cent of world population. These countries include many small but wealthy countries, for example the Bahamas, Bahrain, Taiwan, Israel, Kuwait, Qatar, Singapore, and the United Arab Emirates. Average PPP-based per capita wealth for the whole group was 3.5 times the average for the world. This group too showed greater inequality in per capita wealth than in per capita GDP (CVs of 0.484 and 0.184 , respectively on a PPP basis).

The 39 countries in the upper middle-income group had an average wealth just a little below the world average. This group includes countries like Brazil, Mexico, Poland and Russia. Poland's per capita wealth was close to the world average, while Mexico and Brazil were somewhat lower (81 per cent and 80 per cent respectively on a PPP basis), and Russia stood at 67 per cent of the world mean. (See Appendix V where full details are given for all countries.) Each of these countries had a smaller share of world wealth than of world GDP — in the case of Russia 1.6 per 
cent of the wealth vs. 3.2 per cent of world GDP. Overall, the upper middle-income group accounted for 9.2 per cent of the world household (PPP) wealth, 11.4 per cent of the world population but 13.9 per cent of world GDP. This group also showed greater inequality in per capita wealth than in per capita GDP (CVs of 0.277 and 0.170 , respectively, on a PPP basis).

The lower middle income group includes China, Egypt, Turkey, and the Ukraine. According to our estimates, some of these countries, like Turkey, have a larger share of world wealth than of world GDP. Others, like Egypt and the Ukraine, have a smaller share of wealth than of GDP. However, it is interesting to note that China, which is such an important element in the world distribution, has fairly similar shares of world wealth and GDP, at least on a PPP basis: 8.8 per cent of world household wealth and 10.5 per cent of world GDP. (However, according to official exchange rates, its wealth share is only 2.6 per cent and its GDP share is 3.5.) The collective household wealth of the 59 lower middle income countries amounted to 15.5 per cent of the world total on a PPP basis. This compares to their 33.0 per cent share of world population and their 18.9 per cent of world GDP on a PPP basis. Interestingly, for this group the inequality of per capita wealth fell short of its inequality of GDP per capita (CVs of 0.240 and 0.264 , respectively).

The last group consists of 64 low-income countries. Its collective household net worth on a PPP basis amounted to 8.3 per cent of world wealth, compared to 39.9 per cent of the world's population and 11.3 per cent of world GDP. This group consists of countries such as India, whose average per capita net worth was only 24.7 per cent of the world average but whose per capita GDP was 29.2 per cent of the world average; and Indonesia, whose per capita wealth was 30.2 per cent of the world average and whose GDP per capita was 43.9 per cent of the world average. (Note that our numbers for India and Indonesia, like those of China, are based on actual observations rather than imputations.) The mean per capita PPP wealth of this group was 20.8 per cent of the world average, compared to 24.4 per cent for GDP. For this group, the inequality of wealth per capita was less than its inequality of GDP per capita (CVs of 0.385 and 0.413 , respectively).

19 It is possible that this result is due to the high rate of imputations, especially using region/income group proxies 
Finally, looking at the world as a whole, we find that according to the $\mathrm{CV}$, the inequality of net worth per capita among the 229 countries in the sample was considerably higher than the inequality of GDP per capita. (2.141 compared to 1.769 using official exchange rates). As in most of the country groupings, we find that inequality is considerably greater when measured using official exchange rates than on a PPP basis. (CVs of 1.878 and 1.298 respectively in the per adult data). Given the relatively high level of integration of world capital markets that has now been achieved, the large share of wealth that is held by the wealthy, and the international outlook and investments of large wealth-holders around the world, there is a stronger argument for paying attention to the exchange rate-based inequality results than is the case when studying income inequality or poverty. We return to this point in the next section. Also note that world wealth inequality is lower when measured on a per adult basis (both with official exchange rates and PPP). This reflects the fact that children form a larger percentage of the population in poor countries.

\section{Distribution of Wealth within Countries}

The raw data with which we begin refer to 20 countries for which there is some information on the distribution of wealth across households or individuals. We selected one set of figures for each nation, with a preference for the year 2000, ceteris paribus. To assist comparability across countries, Table 9 adopts a common distribution template consisting of the decile shares reported in the form of cumulated quantile shares (i.e. Lorenz curve ordinates) plus the shares of the top 10 per cent, 5 per cent, 2 per cent, 1 per cent, 0.5 per cent and 0.1 per cent.

The data differ in many significant respects. The economic unit of analysis is most often a household or family, but sometimes an individual or, in the case of the UK, adult persons. Distribution information is usually reported for share of wealth owned by each decile, together with the share of the top 5 per cent and the top 1 per cent of wealth holders. But this pattern is far 
from universal. In some instances information on quantile shares is very sparse; on other occasions, wealth shares are reported for the top 0.5 per cent or even the top 0.1 per cent in the case of France and Switzerland.

The most important respect in which the data vary across countries is the manner by which the information is collected. Household sample surveys are employed in 15 of the 20 countries.20 Survey results are affected by sampling and non-sampling error, as discussed earlier. Nonsampling error, in the form of differential response and under-reporting, tends to reduce estimated inequality and particularly the estimated share of top groups. This occurs because wealthy households are less likely to respond, and because under-reporting is particularly severe for the kinds of financial assets that are especially important for the wealthy — for example equities and bonds. The impact of these errors can be reduced, however, by high income/wealth groups, as has been done in several countries, including the US and Canada. Careful imputations of asset and liabilities are also made in cases where respondents do not answer all questions. 21

Other wealth distribution estimates used here derive from tax records. The French and UK data are based on estate tax returns, while the data for Denmark, Norway, and Switzerland originate from wealth tax records. These data sources have the advantage that 'response' is involuntary, and under-reporting is illegal. However, under-reporting may nonetheless occur, and there are valuation problems that produce analogous results. Wealth tax regulations may assign to some

\footnotetext{
20 The list of countries differs a little from the 13 used in Sections 2 and 3. Here we wish to exploit distributional information from as many countries as possible, and hence added countries with data considerably earlier than 2000: Ireland (1987) and Korea (1988). The hope is that the shape of wealth distribution in these countries was reasonably stable from the late 1980s to the year 2000, even if it is unsafe to use the 1980s values for wealth levels. We are also adding Sweden, since its distributional detail is of interest, although the mean from this source was not judged sufficiently reliable to be used in our levels estimates. The Netherlands was dropped due to insufficient distributional detail.

21 Intensive efforts along these lines are made in the US, where the accuracy of the Survey of Consumer Finances in measuring the shape of the distribution of wealth is considered to be very high. (See Kennickell, 2003 and 2004.) Pioneering new statistical techniques have been used to correct for non-sampling error in some other countries, including Italy (which, however, does not over-sample in the upper tail). Brandolini et al. (2004) have used records of the number of contacts needed to win a response to estimate the differential response relationship, allowing reweighting. A validation study comparing survey and independent amounts from a commercial bank for selected financial assets is used to correct for misreporting. There is also an imputation for non-reported dwellings respondents own (aside from their principal dwelling).
} 
assets a fraction of their market value, and omit other assets altogether. There are also evident differences in the way that debts are investigated and recorded. For most countries the bottom decile of wealth holders is reported as having positive net wealth, but in Sweden the bottom half of the distribution collectively has more debts than assets.

Table 9 shows that wealth concentration varies significantly across countries, but is generally very high. Comparisons of wealth inequality often focus attention on the share of the top 1 per cent. That statistic is only reported for 12 countries, a list that excludes China, Germany, and the Nordic countries apart from Denmark. Estimated shares of the top 1 per cent range from 10.4 per cent in Ireland to 34.8 per cent in Switzerland, with the USA towards the top end of this range at 32.7 per cent. (The sampling frame for the US survey excludes the Forbes 400 richest families; adding them would raise the share of the top 1 per cent by about two percentage points. See Kennickell, 2003, p. 3.) The share of the top 10 per cent, which is available for all 20 countries, ranges from 41.4 per cent in China to 69.8 per cent in the USA.

The differences in wealth concentration across countries in Table 9 are probably attributable in part to differences in data quality. If survey data do not oversample the upper tail, the shares of the richest groups can be depressed very significantly (see for example Davies, 1993): in the absence of corrections for non-sampling error, a reasonable guess is that the share of the top 1 per cent may be underestimated by 5-10 percentage points. The surprisingly low top shares seen here in Australia, Ireland, and Japan may well reflect this phenomenon. One way to attack this problem is to replace, where possible, the survey estimate of the upper tail with figures derived from lists of the very rich (and their wealth) compiled by journalists and others (see Atkinson, 2006, for a review of this form of evidence). While estimates have been prepared on this basis in a few countries, the approach has not been widely pursued and is beyond the scope of this paper.

As is evident in Table 9, the available sources provide a sparse patchwork of quantile shares. In order to move towards estimating the world distribution of wealth, more complete and comparable information is needed on the distribution in each country. To achieve this, missing cell values were imputed using a utility program developed at WIDER which constructs a synthetic sample of 1000 observations that conforms exactly with any given valid set of quantile shares obtained from a distribution of positive values (e.g. incomes). To apply this 'ungrouping' utility, the negative wealth shares reported for Finland, Germany and Sweden were discarded, 
together with the zero shares reported elsewhere, thus treating the cell values as missing observations.

The 20 countries for which wealth distribution data are available include China and India, and hence cover a good proportion of the world's population. They also include most of the rich, populated countries, and hence cover a good proportion of the world's wealth. However, the fact that the list is dominated by OECD members, and is further biased towards Nordic countries, cautions against extrapolating immediately to the rest of the world.

To estimate wealth distribution shares for countries for which no direct information exists, we made use of income distribution data for 145 countries recorded in the WIID dataset, on the grounds that wealth inequality is likely to be correlated — possibly highly correlated — with income inequality across countries. The WIID dataset has many observations for most of the 145 countries. Where possible, we selected the data for household income per capita across individuals for a year as close as possible to 2000, with first priority given to figures on disposable income, then consumption or expenditure. 85 per cent of the income distributions conformed to these criteria. Figures for gross incomes added a further 7 per cent, leaving a residual 8 per cent of countries for which the choices were very limited. The WIDER 'ungrouping' utility was then applied to obtain quantile shares for income (reported in Lorenz curve form) according to the same template employed for wealth distribution.

The common template applied to the wealth and income distributions allows Lorenz curve comparisons to be made for each of the 20 reference countries listed in Table 9. In every instance, wealth shares are lower than income shares at each point of the Lorenz curve: in other words, wealth is unambiguously more unequally distributed than income. Furthermore, the ratios of wealth shares to income shares at various percentile points appear to be fairly stable across countries, supporting the view that income inequality provides a good proxy for wealth inequality when wealth distribution data are not available. Thus, as a first approximation, it seems reasonable to assume that the ratio of the Lorenz ordinates for wealth compared to income are constant across countries, and that these constant ratios (14 in total) correspond to the average 
value recorded for the 20 reference countries. 22 This enabled us to derive estimates of wealth distribution for 124 countries to add to the 20 original countries on which we have direct evidence of wealth inequality.

The group of 144 countries on which we have inequality evidence differs slightly from the group of 166 nations for which mean wealth was estimated from actual data or our regressions in Section 2. Distributional evidence is a more common for populous countries, so the group of 144 now include Cuba, Iraq, Myanmar, Nepal, Serbia, Sudan and Uzbekistan and cover 96.6 per cent of the global population. For the rest of the world, the default of disregarding the remaining countries was again eschewed in favour of imputing wealth distribution figures equal to the (population) weighted average for the corresponding region and income class.

\section{World Distribution}

The final step in the construction of the global distribution of wealth combines the national wealth levels estimated in Section 3 with the wealth distribution data discussed in the previous section. Specifically, the ungrouping utility was applied to each country to generate a sample of 1000 synthetic individual observations consistent with the (actual, estimated or imputed) wealth distribution. These were scaled up by mean wealth, weighted by the population size of the respective country, and merged into a single dataset comprising 228,000 observations. 23 The complete sample was then processed to obtain the minimum wealth and the wealth share of each percentile in the global distribution of wealth. The procedure also provides estimates of the composition by country of each wealth percentile, although these are rough estimates given that the population of each country is condensed into a sample of 1000 , so that a single sample observation for China or India represents more than half a million adults.

\footnotetext{
22 To circumvent aggregation problems, the adjustment ratio was applied to the cumulated income shares (ie Lorenz values) rather than separate quantile income share. We intend to check the validity of this procedure by comparing the 'true' and 'estimated' aggregate wealth distribution over the 20 reference countries.

23 Our data include 229 countries. However, we dropped Pitcairn Island at this point because of its very small population (far less than 1,000 people).
} 
The interpretation of data on personal wealth distribution hinges a great deal on the underlying population deemed to be relevant. Are we concerned principally with the distribution of wealth across all individuals, across adult persons, or across households or families?24 When examining the analogous issue of global income distribution, we support the common practice of assuming (as a first approximation) that the benefits of household expenditure are shared equally among household members, and that each person is weighted equally in determining the overall distribution. However, the situation with wealth is rather different. Personal assets and debts are typically owned by named individuals, and may well be retained by those individuals if they leave the family. Furthermore, while some household assets, especially housing, provide a stream of communal benefits, it is highly unlikely that control of assets is shared equally by household members or that household members will share equally in the proceeds if the asset is sold. Membership of households can be quite fluid (for example, with respect to children living away from home) and the pattern of household structure varies markedly across countries. For these and other reasons, the total number of households is not readily available for many countries. Thus, despite the fact that most of the datasets listed in Table 9 are constructed on a family or household basis, we believe that the distribution of global wealth is best interpreted in terms of the distribution across adults, on the grounds that those under 20 years of age have little formal or actual wealth ownership, and may therefore be neglected in global terms. 25

Tables 10a and 10b summarise our estimates of the distribution of wealth across the global population of 3.7 billion adults with wealth measured at official exchange rates for the year 2000 . The results indicate that only $\$ 2161$ was needed in order to belong to the top half of the world wealth distribution, but to be a member of the top 10 per cent required at least $\$ 61,000$ and membership of the top 1 per cent required more than $\$ 500,000$ per adult. This latter figure is surprisingly high, given that the top 1 per cent group contains 37 million adults and is therefore

\footnotetext{
24 Note that each of these bases was used by at least one country listed in Table 9.

25 The original country level data are generally based on households. We implicitly assume that the shape of the distribution of wealth among adults is the same as that among households, an assumption which would be true if all households contained two adults, if children had zero wealth, and if wealth was equally divided between the adult members.
} 
far from an exclusive club. The entrance fee has presumably grown higher still in the period since the year 2000 .

The figures for wealth shares show that the top 10 per cent of adults own 85 per cent of global household wealth, so that the average member of this group has 8.5 times the global average holding. The corresponding figures for the top 5 per cent, to 2 per cent and top 1 per cent are 71 per cent (14.2 times the average), 51 per cent (25 times the average) and 40 per cent (40 times the average), respectively. This compares with the bottom half of the distribution which collectively owns barely 1 per cent of global wealth. Thus the top 1 per cent own almost 40 times as much as the bottom 50 per cent. The contrast with the bottom decile of wealth holders is even starker. The average member of the top decile nearly 3000 times the mean wealth of the bottom decile, and the average member of the top percentile is more than 13,000 times richer.

Table 10b supplements these results with details of the Gini coefficient for individual countries and for the world as a whole. As mentioned earlier, wealth distribution is unambiguously more unequal than income distribution in all countries which allow comparison. Our wealth Gini estimates for individual countries range from a low of 0.547 for Japan to the high values reported for the USA (0.801) and Switzerland (0.803), and the highest values of all in Zimbabwe (0.845) and Namibia (0.846). The global wealth Gini is higher still at 0.892 . This roughly corresponds to the Gini value that would be recorded in a 10-person population if one person had \$1000 and the remaining 9 people each had $\$ 1$.

By way of comparison Milanovic (2005, p. 108) estimates the Gini for the world distribution of income in 1998 at 0.795 using official exchange rates. It is interesting to note that, while wealth inequality exceeds income inequality in global terms, the gap between the Gini coefficients for world wealth and income inequality — about 10 percentage points — is less than the gap at the country level, which averages about 30 percentage points. This is unavoidable given that an income Gini of 0.795 and a Gini upper bound of 1 , limits the possibilities for higher Gini values. It is also worth pointing out that the relative insensitivity of the Gini coefficient to the tails of the distribution implies that our likely slight underestimation of the top wealth shares will have little impact on the estimated Gini. Furthermore, concentration in the upper tail of the income distribution is also probably underestimated (although to a lesser extent than for wealth), so that the estimated gap between wealth and income inequality is unlikely to be heavily biased. 
We now turn to the composition of each of the wealth quantiles. Table 10a provides a regional breakdown where, due to their population size, China and India are reported separately. It is also convenient to distinguish the high income subset of countries in the Asia-Pacific region (a list which includes Japan, Taiwan, South Korea, Australia, New Zealand and several middle eastern states) from the remaining (mainly low income) nations.

'Thirds' feature prominently in describing the overall pattern of results. India dominates the bottom third of the global wealth distribution, contributing a little under a third ( 27 per cent to be precise) of this group. The middle third of the distribution is the domain of China which supplies more than a third of those in deciles 4-8. At the top end, North America, Europe and highincome Asia monopolise the top decile, each regional group accounting for around one third of the richest wealth holders, although the composition changes a little in the upper tail, with the North American share rising while European membership declines. Another notable feature is the relatively constant membership share of Asian countries other than China and India. However, as the figures indicate, this group is highly polarised, with the high-income subgroup populating the top end of the global wealth distribution and the lower income countries (especially, Indonesia, Bangladesh, Pakistan and Vietnam) occupying the lower tail. The population of Latin America is also fairly even spread across the global distribution but Africa, as expected, is heavily concentrated at the bottom end.

Table 10b provides more details for a selection of countries. The list of countries include all those which account for more than 1 per cent of global wealth or more than 1 per cent of those in the top decile, plus those countries with adult populations exceeding 45 million They have been arranged in order of the number of persons in the top global wealth decile.

The number of members of the top decile depends on three factors: the size of the population, average wealth, and wealth inequality within the country. As expected, the US is in first place, with 25 per cent of the global top decile and 37 per cent of the global top percentile. All three factors reinforce each other in this instance: a large population combining with very high wealth per capita and relatively unequal distribution. Japan features strongly in second place - more strongly than expected, perhaps - with 21 per cent of the global top decile and 27 per cent of the global top percentile. The high wealth per adult and relatively equal distribution accounts for the 
fact that the number of Japanese in the bottom half of the global wealth distribution is insignificant according to our figures. Italy, too, has a stronger showing than expected, for much the same reasons as Japan.

Further down the list, China and India both owe their position to the size of their population. Neither country has enough people in the global top 5 per cent in 2000 to be recorded. While the two countries are expected to be under-represented in the upper tail because of their relatively low mean wealth, their absence here from the top 5 per cent seems anomalous. It may well reflect unreliable wealth data drawn from surveys that do not over-sample the upper tail, data which could be improved by making corrections for differential response and under-reporting. The representation of both China and India has been rising in the annual Forbes list of billionaires, so these countries should not only be represented in an accurate estimate of the membership of the top 5 per cent or top 1 per cent, but also likely supply an increasing number of people in these categories.

For the world's super rich it is natural to compare the wealth of people in different countries using official exchange rates. In today's world capital is highly mobile internationally, and rich people from most countries travel a great deal and may do a considerable amount of their spending abroad. The wealth of one millionaire goes just as far as that of another in Monte Carlo or when shopping at Harrods, irrespective of which country he resides in. Lower down the scale, however, the benefits (and valuations) of asset holdings may depend heavily on the local prices of goods and services. In this case it may be more appropriate to evaluate wealth in terms of what it would buy if liquidated and spent on consumption locally. To address this point, Tables 11a and 11b provide a second set of wealth distribution estimates based on PPP comparisons rather than official exchange rates.

Applying the PPP adjustment increases average wealth level in most countries, and hence the global average, which rises from $\$ 33893$ per adult to $\$ 43628$ per adult. The admission fee for membership of the top wealth groups also increases. The price for entry to the top 10 per cent rises from $\$ 61041$ to $\$ 88035$, but entry to the top 1 per cent increases more modestly, from $\$ 514512$ to $\$ 523264$, reflecting the small impact of PPP adjustments within the richest nations. 
Because the PPP adjustment factor tends to be greater for poorer countries, switching to PPP valuations compresses the variation in average wealth levels across countries and hence provides a more conservative assessment of the degree of world wealth inequality. As a consequence, the estimated share of wealth owned by the richest individuals falls: from 85.1 per cent to 71.1 per cent for the top 10 per cent of wealth holders, for example, and from 39.9 per cent to 31.6 per cent for the top 1 per cent. The overall global Gini value also declines, from 0.892 to 0.802 (although the Gini values for individual countries are unaffected).26

The overall picture suggested by Tables $11 \mathrm{a}$ and $11 \mathrm{~b}$ is much the same as before. India moves a little more into the middle deciles of the global wealth distribution, and both India and China are now deemed to have representatives in the global top 5 per cent, although not the top 1 per cent. Membership of the top 10 per cent is a little more spread regionally, principally due to a decline in the share of Japan, whose membership of the top 10 per cent falls from 20.5 per cent to 14.2 per cent as a result of the decline in wealth per adult from $\$ 227600$ to $\$ 157146$ when measured in PPP terms.

As regards the rankings of individual countries, Brazil, India, Russia, Turkey and Argentina are now all promoted into the exclusive class of countries with more than 1 per cent of the members of the global top wealth decile. The most dramatic rise, however, is that of China which leapfrogs into fifth position with 4.1 per cent of the members. Even without an increase in wealth inequality, a relatively modest rise in average wealth in China will move it up to third position in the global top decile, and overtaking Japan is not a remote prospect.

In summary, it is clear that household wealth is much more concentrated, both in size distribution and geography, when official exchange rates rather than PPP valuations are employed. Thus a somewhat different perspective emerges depending on whether one is interested in the power that wealth conveys in terms of local consumption options or the power to act and have influence on the world financial stage.

\footnotetext{
26 Milanovic (2005, p. 108) reports a world income Gini of 0.642 using PPP. Thus the gap between the world wealth and income Ginis appears to be larger, in absolute terms, on a PPP basis than using official exchange rates, where the gap reported earlier was $0.892-0.795=0.097$.
} 
A number of checks were conducted to test the sensitivity of our results to the assumptions made at various stages. Table 12 begins by summarising the figures recorded earlier for the total world adult population with wealth valued according to official exchange rates (row 1) and PPP (row 2). The next three rows report the corresponding figures when we omit countries for which data has been imputed on the basis of region-income averages. Row 3 discards those with imputed wealth levels; row 4 those without income distribution data (and hence no way of estimating wealth inequality); and row 5 those with either form of imputation. The results show that the regional-income group imputations affect less than 6 per cent of the global adult population and less than 2 per cent of global wealth, so it is not surprising to discover almost no impact on global wealth distribution, apart from a small rise in wealth shares in the top decile attributable to the imputations of wealth levels.

The last two rows take an even more extreme position, excluding all countries other than the 20 nations listed in Table 9 for which direct data exist on wealth distribution. Restricting attention to these 20 countries loses 16 per cent of the world's wealth and 41 per cent of the world's adults. Nevertheless, the figures in row 6 are little different from the row 1 benchmark, with a top 1 per cent share of 37.4 per cent compared to 39.9 per cent, for example, and a Gini value of 0.887 compared to 0.892 .

The final row 7 keeps the same 20 countries but discards the 'true' wealth distribution figures, replacing them instead with the estimate derived from income distribution data that was applied to most countries. The evidence suggests that the estimation procedure tends to slightly reduce wealth inequality at the top of the distribution, with the share of the top 1 per cent falling from 37.4 per cent to 32.8 per cent and the world Gini value from 0.887 to 0.879 . This leads us to conclude that our method of estimating wealth distributions from income distributions may impart a downward bias to global inequality, although the fact that less than 20 per cent of global wealth is affected by the procedure will limit the overall impact.

Other respects also lead us to believe that our estimates of the top wealth shares are conservative. The survey data on which most of our estimates are based under-represent the rich and do not reflect the holdings of the super-rich. Although the SCF survey in the USA does an excellent job in the upper tail, its sampling frame explicitly omits the 'Forbes 400' wealthiest US families. 
Surveys in other countries do not formally exclude the very rich, but it is rare for them to be captured. This means that our estimated shares of the top 1 per cent and 10 per cent are likely to err on the low side. A rough idea of the possible size of the error can be gained by noting that the total wealth of the world's billionaires reported by Forbes for the year 2000, \$2.16 trillion, was 1.7 per cent of the total world household wealth we find here, of \$125.3 trillion.

To explore the top tail in more detail, a Pareto-type graph was constructed, plotting the logarithm of the number of adults above wealth level $w$ against the logarithm of $w$. Given the fact that each of our sample observations can represent many tens of thousands of adults, one would not expect great accuracy in the extreme upper tail. Figure 3 shows this to be the case, with evident lumpiness appearing at wealth levels above \$5 million. However, the relationship in the range from \$250,000 to \$5 million appears stable and remarkably well approximated by a Pareto distribution. Fitting a Pareto distribution in this range and extrapolating to the highest echelons of the wealth distribution, yielded the following predictions for the number of high wealth holders and the super rich:

\begin{tabular}{ll}
\hline Wealth (\$ million) & Number above \\
\hline 1 & 13568229 \\
10 & 451809 \\
100 & 15010 \\
1000 & 499 \\
\hline
\end{tabular}

Thus extrapolating our upper tail leads us to predict 499 dollar billionaires in the year 2000. The number estimated by Forbes magazine for the year 2000 was 492. Given the very different ways in which the two estimates were derived, the degree of similarity is astonishing and gives us confidence that our figures are not too far from the mark. 27 Further support comes from the fact

27 Merrill-Lynch in its 2001 World Wealth Report estimated 7.2 million individuals worldwide with net worth in excess of \$1million. This is less than our figure of 13.6 million. Unlike the Forbes data, the Merrill-Lynch numbers are not based on lists of named individuals, but largely use public sources of data, as we do. Their methods are not 
that the Forbes data classifies 200 of the 492 dollar billionaires (i.e. 40.7 per cent) as US citizens, a fraction that again conforms very closely with the data reported in Table 10b which gave a US share of 37.4 per cent for the top 1 per cent and suggested that the share would rise further as wealth increased.

\section{Conclusion}

This paper has provided a first estimate of the world distribution of household wealth. We have seen that the distribution is highly concentrated - in fact much more concentrated than the world distribution of income, or the distribution of wealth within all but a few of the world's countries. While a typical share of the top 10 per cent of wealth-holders within a country would be about 50 per cent, and the median Gini around 0.7, we have estimated that for the world as a whole the share of the top 10 per cent was 85 per cent in the year 2000 and the Gini equalled 0.892 using official exchange rates, Milanovic (2005) estimates that the world income Gini was 0.795 in 1998. While wealth (and income) concentration is somewhat less when the estimates are done on a PPP basis, we have argued that the large share of wealth that is owned by people who can readily travel and invest globally means that converting at official exchange rates is preferable for many purposes when one is studying the distribution of wealth, rather than income distribution or poverty.

Much of the data that is used here comes from household surveys. For the wealthiest country, the US, which supplies 25 per cent of the world's top 10 per cent of wealth-holders on an official exchange rate basis (20 per cent using PPP), this is not a big problem. Sophisticated techniques have been used by the Federal Reserve Board to make its triennial Survey of Consumer Finance a reliable instrument. Less striking, but still effective steps have been taken in some of the other wealthiest countries. While the super rich are not represented in these data, in terms of measuring the overall degree of inequality we have seen that that is not a major deficiency. On the other hand, surveys in the major developing countries appear to have a particular problem in capturing

well documented, so it is difficult to know why the number of millionaires is less than our estimate. But one likely explanation is that the Merrill Lynch wealth valuations exclude the family home and all consumer durables. 
the upper tail. This means that while we have reasonable confidence in our estimates, there is a non-negligible error bound that must be placed on them.

In evaluating the results obtained here it is important to keep in mind that the quality of the estimates depends only in part on the accuracy of the distributional information that has been assembled. It also depends on the accuracy of our estimates of mean household wealth in the countries studied. Here we are on safer ground. For 33 countries, including all of the world's major OECD economies, we have data on the household sector's financial balance sheet. And for 18 of those countries we also have reasonable estimates of non-financial assets. These estimates are often formed in conjunction with Flow of Funds numbers or the National Accounts. There is a solid basis of good numbers from financial institutions and government statistical agencies in these exercises.

Our study of wealth levels and composition across countries is not only important in providing a key ingredient in estimating the world distribution of wealth. It is also of independent interest. First, it gives us a picture of how wealth composition varies, not only with the stage of development, but across countries at similar income levels due to institutional and traditional differences, varying importance of public pensions, and other factors. Our empirical work has shown how the importance of both financial assets and borrowing rises sharply with per capita income and the development of financial markets. Conversely, we have seen how balance sheets in poor countries are still dominated by land and other tangible assets. Secondly, we get a snapshot of what Milanovic (2002, 2005) and others refer to as 'international inequality', that is inequality between countries. On an official exchange rate basis per capita household wealth ranged from about $\$ 1,100$ for India to $\$ 144,000$ for the United States in the year 2000. We have also found that differences are large even for countries at a similar stage of development. Thus, differences between countriesmake an important contribution to inequality in the world distribution of household wealth. Even if the current level of wealth inequality within countries proved to be enduring, one may hope for a significant reduction in world wealth inequality as convergence takes place in wealth between nations.

Two caveats to conclusions about wealth inequality between countries ('international inequality') are that the concentration is smaller when we measure on a PPP basis, and also less on a per adult basis. Thus, for example, while the coefficient of variation for international 
inequality is 2.141 on a per capita and official exchange rate basis, it is only 1.298 on a per adult and PPP basis.

There is huge room for improvement in the study of household wealth from a global perspective. Household balance sheets and wealth surveys need to be generated in more countries. These are completely lacking in Latin America, and almost completely absent in Africa and most of Asia as well. Financial development is a key aspect of economic growth and human development. Without the relevant data it is impossible to see what progress is being made. Improvements in data quality, particularly in survey data, must also occur. The task is far from hopeless, however, and great strides have been taken in quite a few countries. The mere fact that regular wealth surveys are conducted in the world's two largest and most dynamic developing countries, China and India, is very encouraging. As surveys are conducted in more developing and transition countries, and as techniques for achieving greater accuracy, especially in the upper tail, are applied in more countries, we will get a much better picture of the composition and distribution of household wealth around the globe. 


\section{References}

Ammermüller, A., Weber, A. and Westerheide P. (2005). Abschlussbericht zum Forschungsauftrag des Bundesministeriums für Gesundheit und Soziale Sicherung: Die Entwicklung und Verteilung des Vermögens privater Haulshalte unter besonderer Berücksichtigung de Produktivvermögens. Zentum für Europäische Wirtscaftsforschung.

Aron, Janine, John Muellbauer, and Johan Prinsloo (2006). 'Estimating the Balance Sheet of the Personal Sector in an Emerging Market Country, South Africa 1970-2005’. Working paper, WIDER/UNU Project on Personal Assets From a Global Perspective.

Atkinson, Anthony B. and A.J. Harrison (1978). Distribution of Personal Wealth in Britain. Cambridge: Cambridge University Press.

Atkinson, Anthony B. (2006), 'Concentration Among the Rich', Working paper, WIDER/UNU Project on Personal Assets From a Global Perspective.

Australian Bureau of Statistics (2005). Household Income and Income Distribution Available from: http://www.abs.gov.au

Babeau, André and Teresa Sbano (2003). 'Household Wealth in the National Accounts of Europe, the United States and Japan’. OECD Statistics Working Papers 2003/2.

Banco de Espana (2005)'Survey of Household Finances (EFF): Description, Methods and Preliminary Results’. Economic Bulletin January 2005.

Board of Governors of the Federal Reserve System (2003), Guide to Flow of Funds Accounts, Volume 1.

Bramall, C. (2001), 'The Quality of China’s Household Income Surveys', The China Quarterly 167: 689-705.

Brandolini, A., Cannari L., D’Alession G. and Faiella I. (2004). Household Wealth Distribution in Italy in the 1990s.Termi di discussione No 530. Rome: Bank of Italy.

Davies, James B. (1993). 'The Distribution of Wealth in Canada'. Research in Economic Inequality 4: 159-180.

Davies, James B. and A.F. Shorrocks (2000). 'The Distribution of Wealth', Ch. 11 of Atkinson, Anthony B. and François Bourguignon, Handbook of Income Distribution Volume I, Amsterdam: Elsevier: 605-676.

Davies, James B. and Anthony Shorrocks (2005). 'Wealth Holdings in Developing and Transition Countries'. Paper presented at a meeting of the Luxembourg Wealth Study, Perugia, January. Available

Dell, F., Piketty, T. and Saez, E. (2005). Income and Wealth Concentration in Switzerland over the $20^{\text {th }}$ Century. Center for Economic Policy Research, Discussion Paper Series No. 5090. London: CEPR. 
Goldsmith, Raymond W. (1985). Comparative National Balance Sheets, A Study of Twenty Countries, 1688-1978 Chicago: University of Chicago Press

Greene, William H. (1993), Econometric Analysis, Second Edition New York: Macmillan.

Headey, Bruce, Gary Marks and Mark Wooden (2005). 'The Structure and Distribution of Household Wealth in Australia'. Australian Economic Review 38: 159-175.

Inland Revenue Statistics (2005). Distribution of Personal Wealth. Available from http://www.hmrc.gov.uk/stats/personal_wealth/menu.htm

International Monetary Fund (2005). Global Financial Stability Report, Market Developments and Issues. International Capital Markets Department. Available at http://www.imf.org/External/Pubs/FT/GFSR/2005/01/index.htm

Japan Statistics Bureau (2005). National Survey of Family Income and Expenditure 1999 [Internet]. Available from: http://www.stat.go.jp/english/data/zensho/index.htm

Kennickell, A. (2003). 'A Rolling Tide: Changes in the Distribution of Wealth in the US, 19892001’. Levy Economics Institute of Bard College, Working Paper No. 393.

Kennickell, Arthur B. (2004). 'The Good Shepherd: Sample Design and Control for Wealth Measurement in the Survey of Consumer Finances', presented at the Perugia meeting of the Luxembourg Wealth Study, January 2005.

King, M.A. and J.I. Leape (1998). 'Wealth and portfolio composition: theory and evidence'. Journal of Public Economics 69: 155-193.

Lane, Philip, and Gian Maria Milesi-Ferretti (2000). 'The External Wealth of Nations, Measures of Foreign Assets and Liabilities For Industrial and Developing Countries', working paper.

Leipziger, D.M., Dollar, D., Shorrocks, A.F. and Song, S.Y. (1992). The Distribution of Income and Wealth in Korea. Washington: The World Bank.

Mauro, Paulo, Nathan Sussman and Yishay Yafeh (forthcoming). Emerging Markets and Financial Globalization, Sovereign Bond Spreads in 1870-1913 and Today. Oxford: Oxford University Press.

Milanovic, Branko (2002). 'True World Income Distribution, 1988 and 1993: First Calculation Based on Household Surveys Alone’, Economic Journal 112: 51-92.

Morissette, R. , Zhang, X. and Drolet, M. (2002). The Evolution of Wealth Inequality in Canada 1984-1999. No. 187, Feb 22. Ottawa: Statistics Canada.

National Sample Survey Organization. (2005). Household Assets and Liabilities in India (as on 30.06.2002): NSS 59 ${ }^{\text {th }}$ round (January-December 2003). Government of India: Ministry of Statistics and Programme Implementation.

Nolan , B. (1991). The Wealth of Irish Households: What Can We Learn from Survey Data? Dublin: Combat Poverty Agency. 
OECD (2005). Source OECD National Accounts Statistics. National Accounts of OECD Countries: Volume IIIb - Financial Balance Sheets - Stocks Vol 2005 release 02.

Piketty, T., Postel-Vinay G., Rosenthal, J-L. (2003). Wealth Concentration in a Developing Economy: Paris and France, 1807-1994. December 2003.

Renwei, Z., and Sing, S. (2005). 'The Distribution of Wealth in China'. Institute of Economics, Chinese Academy of Social Sciences, processed.

Spånt, R. (1982) 'The distribution of household wealth in some developed countries. A comparative study of Sweden, Denmark, France, Germany, United Kingdom and United States', in D. Kessler, A. Masson and D. Strauss-Kahn, eds. Accumulation et Répartition de Patrimoines. Paris: CNRS and Economica.

Statistics Canada (2001). The Assets and Debts of Canadians: An overview of the results of the Survey of Financial Security. Ottawa: Statistics Canada.

Statistics Finland (2000). Kotitalouksien varallisuus 1998. Income and Consumption 2000:26. Helsinki: Statistics Finland.

Statistics New Zealand (2002). The Wealth of New Zealanders: A Report on Their Assets and Debts. Wellington: Household Economic Statistics Division Statistics New Zealand.

Statistics Norway (2005). Income and Property Statistics for Households [Internet]. Available from http://www.ssb.no/english/subjects/05/01/ifhus_en/

Statistics Sweden (2004). Wealth Statistics 2004. Örebro: Statistics Sweden.

UniCredit Group, ‘New Europe Household Wealth Monitor’, November 2005.

Wolff, Edward N., ed. (1987). International Comparisons of the Distribution of Household Wealth. Oxford: Clarendon Press.

Wolff, Edward N. (1996). 'International Comparisons of Wealth Inequality', Review of Income and Wealth 42: 433-451.

Wolff, Edward N. (forthcoming). 'Chapter 1. Introduction', in Edward N. Wolff (ed.), International Perspectives on Household Wealth, Edward Elgar Publishing Ltd.

World Bank (2005). Where is the Wealth of Nations? Measuring Capital for the XXI Century.

Zellner, A. (1962) 'An Efficient Method of Estimating Seemingly Unrelated Regressions and Tests of Aggregation Bias’, Journal of the American Statistical Association 57: 500-509. 
Table 1 Coverage of wealth levels data, year 2000

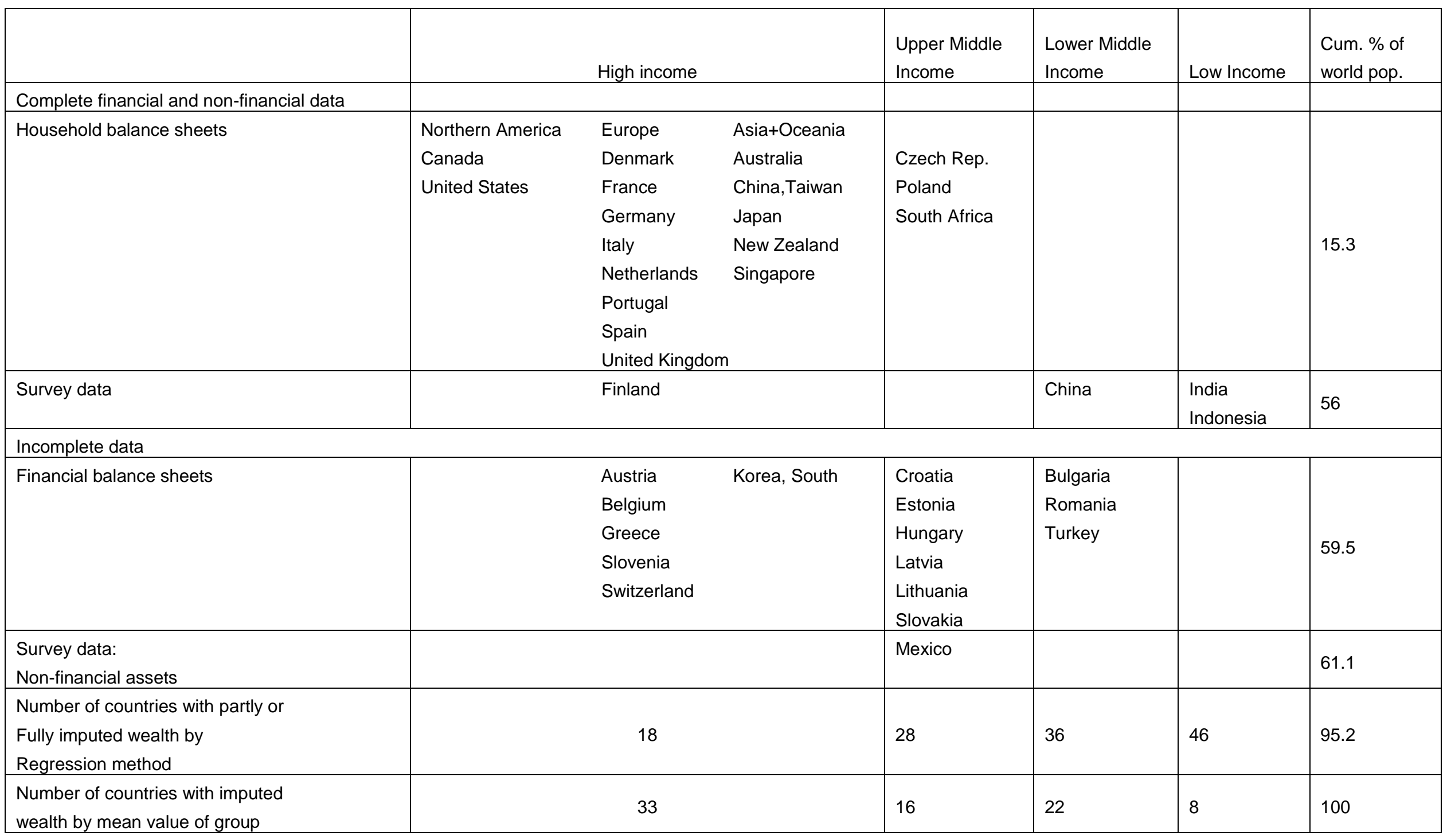


Table 2: Comparison of full household balance sheets

\begin{tabular}{|c|c|c|c|}
\hline Country & Sector Definition & Non-housing real assets & $\begin{array}{l}\text { Consumer } \\
\text { durables }\end{array}$ \\
\hline Australia & households & yes & imputed \\
\hline Canada & households + NPOs & yes & Yes \\
\hline China, Taiwan & households & yes & Yes \\
\hline Czech Republic & households & yes & imputed \\
\hline Denmark & households + NPOs & yes & imputed \\
\hline France & households + NPOs & yes & imputed \\
\hline Germany & households & yes & Yes \\
\hline Italy & households & yes (only durables) & yes \\
\hline Japan & households & yes & imputed \\
\hline Netherlands & households + NPOs & no & imputed \\
\hline New Zealand & households & yes (only land) & imputed \\
\hline Poland & households & no & Imputed \\
\hline Portugal & households + NPOs & yes (only land) & Imputed \\
\hline Singapore & households & no & Imputed \\
\hline South Africa & households + NPOs & yes & Yes \\
\hline Spain & households + NPOs & yes (only real estate) & Imputed \\
\hline United Kingdom & $\begin{array}{l}\text { households (correted for } \\
\text { NPOs) }\end{array}$ & yes & Imputed \\
\hline United States & $\begin{array}{l}\text { households (corrected for } \\
\text { NPOs) }\end{array}$ & yes & Yes \\
\hline
\end{tabular}

Note: NPOs are non-profit organizations serving households. 
Table 3: Composition of household wealth in household balance sheets, 2000

\begin{tabular}{|c|c|c|c|c|c|c|c|c|}
\hline & $\begin{array}{l}\text { Non- } \\
\text { financial } \\
\text { assets } \\
\text { as } \% \text { of } \\
\text { total } \\
\text { assets }\end{array}$ & $\begin{array}{l}\text { Housing } \\
\text { assets } \\
\text { as \% of } \\
\text { non- } \\
\text { financial } \\
\text { assets }\end{array}$ & $\begin{array}{l}\text { Financial } \\
\text { assets as } \\
\% \text { of total } \\
\text { assets }\end{array}$ & $\begin{array}{l}\text { Liquid } \\
\text { assets } \\
\text { as \% of } \\
\text { financial } \\
\text { assets }\end{array}$ & $\begin{array}{l}\text { Shares } \\
\text { and } \\
\text { equities } \\
\text { as \% of } \\
\text { financial } \\
\text { assets }\end{array}$ & $\begin{array}{l}\text { Other } \\
\text { financial } \\
\text { assets }^{a} \\
\text { as } \% \text { of } \\
\text { financial } \\
\text { assets }\end{array}$ & $\begin{array}{l}\text { Total } \\
\text { assets } \\
\%\end{array}$ & $\begin{array}{l}\text { Liabilities } \\
\text { as \% of } \\
\text { total } \\
\text { assets }\end{array}$ \\
\hline \multicolumn{9}{|c|}{ Household balance sheets } \\
\hline Australia & 59 & 35 & 41 & 22 & 20 & 58 & 100 & 17 \\
\hline Canada & 43 & 46 & 57 & 25 & 32 & 43 & 100 & 18 \\
\hline China, Taiwan & 41 & 48 & 59 & 39 & 32 & 29 & 100 & 10 \\
\hline Czech Rep. & 66 & na & 34 & 60 & 24 & 16 & 100 & 9 \\
\hline Denmark & 45 & 52 & 55 & 21 & 54 & 48 & 100 & 30 \\
\hline France & 60 & 49 & 40 & 33 & 32 & 35 & 100 & 11 \\
\hline Germany & 60 & 70 & 40 & 34 & 37 & 29 & 100 & 16 \\
\hline Italy & 58 & 86 & 42 & 23 & 55 & 21 & 100 & 3 \\
\hline Japan & 50 & na & 50 & 53 & 16 & 31 & 100 & 14 \\
\hline Netherlands & 46 & 83 & 54 & 19 & 24 & 57 & 100 & 16 \\
\hline New Zealand & 68 & 88 & 32 & 35 & 40 & 25 & 100 & 20 \\
\hline Poland & 80 & 78 & 20 & 59 & 25 & 17 & 100 & 3 \\
\hline Portugal & 51 & 77 & 49 & 47 & 38 & 15 & 100 & 19 \\
\hline Singapore & 55 & 86 & 45 & 44 & 21 & 35 & 100 & 18 \\
\hline South Africa & 35 & 47 & 65 & 21 & 20 & 60 & 100 & 15 \\
\hline Spain & 69 & 88 & 31 & 40 & 43 & 17 & 100 & 10 \\
\hline UK & 47 & 74 & 53 & 21 & 25 & 57 & 100 & 13 \\
\hline USA & 33 & 80 & 67 & 13 & 51 & 36 & 100 & 15 \\
\hline \multicolumn{9}{|c|}{ Financial balance sheets } \\
\hline Austria & & & & 22 & 20 & 58 & & \\
\hline Belgium & & & & 55 & 26 & 19 & & \\
\hline Bulgaria $^{b}$ & & & & 88 & 5 & 7 & & \\
\hline Croatia $^{\mathrm{b}}$ & & & & 85 & 6 & 9 & & \\
\hline Estonia & & & & 26 & 54 & 20 & & \\
\hline Greece & & & & 44 & 51 & 4 & & \\
\hline Hungary & & & & 43 & 43 & 14 & & \\
\hline Korea, South & & & & 61 & 18 & 21 & & \\
\hline Latvia & & & & 53 & 44 & 3 & & \\
\hline Lithuania & & & & 33 & 40 & 27 & & \\
\hline Romania $^{b}$ & & & & 76 & 21 & 3 & & \\
\hline Slovakia $^{b}$ & & & & 74 & 12 & 14 & & \\
\hline Slovenia & & & & 52 & 31 & 17 & & \\
\hline Switzerland & & & & 21 & 38 & 41 & & \\
\hline Turkey $^{\mathrm{b}}$ & & & & 62 & 31 & 6 & & \\
\hline
\end{tabular}

Note: ${ }^{\mathrm{a}}$ Other financial assets include insurance and pension reserves and other accounts receivable.

${ }^{\mathrm{b}}$ Composition from year 2004. 
Table 4: Composition of household wealth in survey data, 2000

\begin{tabular}{|c|c|c|c|c|c|c|c|c|}
\hline & $\begin{array}{l}\text { Non- } \\
\text { financial } \\
\text { assets } \\
\text { as } \% \text { of } \\
\text { total } \\
\text { assets }\end{array}$ & $\begin{array}{l}\text { Housing } \\
\text { assets } \\
\text { as \% of } \\
\text { non- } \\
\text { financial } \\
\text { assets }\end{array}$ & $\begin{array}{l}\text { Financial } \\
\text { assets as } \\
\% \text { of total } \\
\text { assets }\end{array}$ & $\begin{array}{l}\text { Liquid } \\
\text { assets } \\
\text { as \% of } \\
\text { financial } \\
\text { assets }\end{array}$ & $\begin{array}{l}\text { Shares } \\
\text { and } \\
\text { equities } \\
\text { as \% of } \\
\text { financial } \\
\text { assets }\end{array}$ & $\begin{array}{l}\text { Other } \\
\text { financial } \\
\text { assets }^{a} \\
\text { as } \% \text { of } \\
\text { financial } \\
\text { assets }\end{array}$ & $\begin{array}{l}\text { Total } \\
\text { assets \% }\end{array}$ & $\begin{array}{l}\text { Liabilities } \\
\text { as \% of } \\
\text { total } \\
\text { assets }\end{array}$ \\
\hline Australia & 68 & 79 & 32 & 14 & 21 & 64 & 100 & 14 \\
\hline Canada & 71 & 54 & 29 & 19 & 23 & 58 & 100 & 16 \\
\hline China $^{\mathrm{b}}$ & 78 & 73 & 22 & 0 & na & $\mathrm{Na}$ & 100 & 1 \\
\hline Finland & 83 & 91 & 17 & 51 & 36 & 14 & 100 & 12 \\
\hline Germany & 76 & na & 24 & 46 & 24 & 30 & 100 & 15 \\
\hline India & 95 & 30 & 5 & 92 & 5 & 3 & 100 & 3 \\
\hline Indonesia & 97 & 47 & 3 & na & na & $\mathrm{Na}$ & 100 & 2 \\
\hline Italy & 78 & 88 & 18 & 40 & 39 & $\mathrm{Na}$ & 100 & 2 \\
\hline Japan & 70 & 77 & 30 & 59 & 34 & 29 & 100 & 10 \\
\hline Netherlands & 80 & 88 & 21 & 37 & 43 & 20 & 100 & 27 \\
\hline New Zealand & 72 & 51 & 28 & 21 & 21 & 58 & 100 & 16 \\
\hline Spain & 87 & 67 & 13 & 40 & 38 & 22 & 100 & 9 \\
\hline USA & 58 & 55 & 42 & 15 & 39 & 46 & 100 & 12 \\
\hline
\end{tabular}

Note: ${ }^{\mathrm{a}}$ Other financial assets include insurance and pension reserves and other accounts receivable. ${ }^{\mathrm{b}}$ Housing assets are net of associated debts; Liabilities exclude housing debt. 
Table 5: Net worth per capita from household balance sheet and survey data, 2000

\begin{tabular}{|c|c|c|c|c|}
\hline & $\begin{array}{r}\text { Net worth } \\
\text { per capita }^{a}\end{array}$ & $\begin{array}{l}\text { Real GDP } \\
\text { per capita }^{\text {b }}\end{array}$ & $\begin{array}{r}\text { Personal } \\
\text { disposable income } \\
\text { per capita }^{c}\end{array}$ & $\begin{array}{l}\text { Real Cons. } \\
\text { per capita }^{b}\end{array}$ \\
\hline \multicolumn{5}{|l|}{ Household balance sheet data } \\
\hline \multicolumn{5}{|l|}{ PPP } \\
\hline Mean & 85,682 & 22,921 & 13,811 & 14,342 \\
\hline Median & 90,906 & 23,917 & 14,739 & 15,672 \\
\hline Coeff. of variation & 0.427 & 0.311 & 0.326 & 0.319 \\
\hline Highest net worth: USA & 143,727 & 35,619 & 25,480 & 24,313 \\
\hline Lowest net worth: South Africa & 16,266 & 8,017 & 4,691 & 5,210 \\
\hline \multicolumn{5}{|l|}{ Exchange rates } \\
\hline Mean & 76,479 & 20,006 & 12,020 & 12,486 \\
\hline Median & 73,654 & 21,425 & 12,145 & 12,708 \\
\hline Coeff. of variation & 0.594 & 0.519 & 0.522 & 0.525 \\
\hline Highest net worth: USA & 143,727 & 35,619 & 25,480 & 24,313 \\
\hline Lowest net worth: South Africa & 5,977 & 2,946 & 1,724 & 1,914 \\
\hline \multicolumn{5}{|l|}{ Survey data } \\
\hline \multicolumn{5}{|l|}{ PPP } \\
\hline Mean & 59,010 & 20,461 & 12,485 & 13,231 \\
\hline Median & 60,614 & 23,917 & 12,798 & 15,197 \\
\hline Coeff. of variation & 0.672 & 0.496 & 0.527 & 0.504 \\
\hline Highest net worth: USA & 143,857 & 35,619 & 25,480 & 24,313 \\
\hline Lowest net worth: India & 6,513 & 2,684 & 1,916 & 1,406 \\
\hline \multicolumn{5}{|l|}{ Exchange rates } \\
\hline Mean & 53,251 & 18,031 & 10,947 & 11,661 \\
\hline Median & 45,176 & 20,338 & 11,557 & 12,708 \\
\hline Coeff. of variation & 0.836 & 0.663 & 0.700 & 0.658 \\
\hline Highest net worth: USA & 143,857 & 35,619 & 25,480 & 24,313 \\
\hline Lowest net worth: India & 1,112 & 458 & 327 & 240 \\
\hline
\end{tabular}

Notes and sources: all figures are in year 2000 , US\$. ${ }^{a}$ Source for the first panel: flow of funds data, national balance sheets and financial balance sheets augmented with estimates of housing assets. In the third panel the original survey data are from close to year 2000 . The numbers have been adjusted by the real growth rate per capita. ${ }^{b}$ Source: Penn World Table 6.1. ' Source: The Economist Intelligence Unit. 
Table 6: Correlations of net worth per capita with income per capita, 2000

\begin{tabular}{|c|c|c|c|c|c|c|c|}
\hline Country & $\begin{array}{r}\text { Net worth } \\
\text { per capita }^{\mathrm{a}}\end{array}$ & $\begin{array}{l}\text { Real GDP } \\
\text { per capita }^{b}\end{array}$ & $\begin{array}{r}\text { Personal } \\
\text { disposable income } \\
\text { per capita }^{\mathrm{c}} \\
\end{array}$ & $\begin{array}{l}\text { Real Cons. } \\
\text { per capita }^{\text {b }}\end{array}$ & $\begin{array}{r}\text { Ln (net worth } \\
\text { per capita) }^{\mathrm{a}}\end{array}$ & $\begin{array}{r}\text { Ln (personal } \\
\text { disposable income } \\
\text { per capita) } \\
\end{array}$ & $\begin{array}{r}\text { Ln (real cons. } \\
\text { per capita) }\end{array}$ \\
\hline \multicolumn{8}{|c|}{ Household balance sheet data } \\
\hline \multicolumn{8}{|c|}{ Correlations with: } \\
\hline \multicolumn{8}{|c|}{ A. Net worth per capita } \\
\hline$P P P$ & 1.000 & 0.739 & 0.841 & 0.715 & & & \\
\hline Exchange rates & & 0.848 & 0.920 & 0.860 & & & \\
\hline \multicolumn{8}{|c|}{ B. Ln (net worth per capita) } \\
\hline$P P P$ & & & & & 1.000 & 0.923 & 0.825 \\
\hline Exchange rates & & & & & 1.000 & 0.975 & 0.940 \\
\hline \multicolumn{8}{|l|}{ Survey data } \\
\hline \multicolumn{8}{|l|}{ Correlations with: } \\
\hline \multicolumn{8}{|c|}{ A. Net worth per capita } \\
\hline$P P P$ & 1.000 & 0.866 & 0.938 & 0.890 & & & \\
\hline Exchange rates & 1.000 & 0.908 & 0.958 & 0.922 & & & \\
\hline \multicolumn{8}{|c|}{ B. Ln (net worth per capita) } \\
\hline$P P P$ & & & & & 1.000 & 0.979 & 0.955 \\
\hline Exchange rates & & & & & 1.000 & 0.993 & 0.979 \\
\hline
\end{tabular}

Note: all figures are in year 2000, US\$. See Table 5 for technical notes. 
Table 7: Regressions of wealth components

Independent variables

Dependent variables

\begin{tabular}{|c|c|c|c|c|c|c|c|c|}
\hline & \multicolumn{2}{|c|}{ Log of non-financial wealth } & \multicolumn{3}{|c|}{ Log of financial wealth } & \multicolumn{3}{|c|}{ Log of liabilities } \\
\hline & (1a) & (1b) & $(2 a)$ & $(2 b)$ & $(2 c)$ & (3a) & $(3 b)$ & (3c) \\
\hline \multirow[t]{2}{*}{ Constant } & .548 & .435 & $-2.683 \#$ & $-2.720 * *$ & $-2.748^{\star *}$ & $-9.268^{\star \star}$ & $-8.326^{\star \star}$ & $-8.659 * *$ \\
\hline & $(0.949)$ & $(.527)$ & $(1.459)$ & $(.735)$ & $(.735)$ & $(.922)$ & $(.874)$ & $(.737)$ \\
\hline \multirow[t]{2}{*}{ Log of real cons per capita } & $1.038^{\star *}$ & $1.028^{\star \star}$ & $1.191^{\star \star}$ & $1.171^{\star *}$ & $1.177^{\star \star}$ & $1.578^{\star *}$ & $1.427^{\star \star}$ & $1.487^{\star \star}$ \\
\hline & $(.079)$ & $(.053)$ & $(.158)$ & $(.110)$ & $(.110)$ & $(.151)$ & $(.137)$ & $(.114)$ \\
\hline \multirow[t]{2}{*}{ Log of population density } & $.119 *$ & $.121^{\star \star}$ & & & & & & \\
\hline & $(.044)$ & $(.041)$ & & & & & & \\
\hline \multirow[t]{2}{*}{ Log of market cap. rate } & & & $.465^{\star \star}$ & $.506 * \star$ & $.502^{\star \star}$ & & & \\
\hline & & & $(.132)$ & $(.098)$ & $(.098)$ & & & \\
\hline \multirow[t]{2}{*}{ Log of pensions as a $\%$ of $C$} & & & -.118 & & & & & \\
\hline & & & $(.153)$ & & & & & \\
\hline \multicolumn{3}{|c|}{ Log of domestic credits available to the private } & & & & $.822^{\star \star}$ & $.916^{\star \star}$ & $.865^{\star \star}$ \\
\hline \multicolumn{3}{|l|}{ sector } & & & & $(.183)$ & $(.172)$ & $(.164)$ \\
\hline \multirow[t]{2}{*}{ Income Gini } & -.006 & & .005 & & & & & \\
\hline & $(.009)$ & & $(.018)$ & & & & & \\
\hline \multirow[t]{2}{*}{ Survey dummy } & .115 & & $-1.219 * *$ & $-1.535^{\star \star}$ & $-1.516^{\star *}$ & $-.832 \#$ & -.280 & \\
\hline & $(.233)$ & & $(.403)$ & $(.335)$ & $(.334)$ & $(.469)$ & $(.400)$ & \\
\hline $\mathrm{R}^{2}$ & .9513 & .9495 & & & & & & \\
\hline$" \mathrm{R}^{2 n}$ & & & .9378 & .9501 & .9501 & .9331 & .9330 & .9320 \\
\hline RMSE & .336 & .325 & .440 & .467 & .467 & .591 & .621 & .625 \\
\hline Sample size & 23 & 23 & 34 & 38 & 38 & 34 & 38 & 38 \\
\hline
\end{tabular}

Note: The sample for the non-financial regressions consists of 18 countries with HBS data and 5 with survey data. The sample for the financial and liabilities regressions consist of 34 countries with HBS or financial balance sheet data and 4 with survey data. In the non-financial assets regression, Ordinary Least Squares are used. In the financial assets and liabilities regressions, the Seemingly Unrelated Regressions (SUR) estimation method is used. Standard errors in parenthesis. Significance levels: \# $-10 \%$ level; *-5\% level; $*$ - $1 \%$ level. 
Table 8: The distribution of net worth by World Bank country group, 2000

\begin{tabular}{|c|c|c|c|c|c|c|}
\hline World Bank country group & $\begin{array}{r}\text { Share of } \\
\text { world } \\
\text { population } \\
\end{array}$ & $\begin{array}{l}\text { Net worth } \\
\text { per capita }\end{array}$ & $\begin{array}{l}\text { Net worth } \\
\text { per adult }\end{array}$ & $\begin{array}{r}\text { Percent of } \\
\text { world net worth } \\
\text { per capita } \\
\end{array}$ & $\begin{array}{r}\text { Real } \\
\text { GDP per } \\
\text { capita }\end{array}$ & $\begin{array}{l}\text { Percent of } \\
\text { world GDP }\end{array}$ \\
\hline High income OECD (24) & 14.81 & & & & & \\
\hline PPP & & 113,675 & 151,308 & 63.73 & 27,367 & 53.55 \\
\hline Coeff. of variation (weighted) & & 0.260 & 0.278 & & 0.233 & \\
\hline Exchange rates & & 115,565 & 153,824 & 83.29 & 27,430 & 76.92 \\
\hline Coeff. of variation (weighted) & & 0.377 & 0.379 & & 0.328 & \\
\hline High income non-OECD (43) & 0.93 & & & & & \\
\hline PPP & & 91,748 & 147,524 & 3.23 & 21,475 & 2.35 \\
\hline Coeff. of variation (weighted) & & 0.484 & 0.342 & & 0.184 & \\
\hline Exchange rates & & 81,233 & 123,485 & 3.67 & 17,708 & 3.08 \\
\hline Coeff. of variation (weighted) & & 0.534 & 0.406 & & 0.233 & \\
\hline Upper middle income (39) & 11.37 & & & & & \\
\hline PPP & & 21,442 & 33,968 & 9.23 & 9,342 & 13.91 \\
\hline Coeff. of variation (weighted) & & 0.277 & 0.285 & & 0.170 & \\
\hline Exchange rates & & 9,626 & 15,249 & 5.33 & 4,058 & 8.74 \\
\hline Coeff. of variation (weighted) & & 0.553 & 0.602 & & 0.456 & \\
\hline Lower middle income (59) & 33.01 & & & & & \\
\hline PPP & & 12,436 & 19,445 & 15.54 & 4,446 & 18.90 \\
\hline Coeff. of variation (weighted) & & 0.240 & 0.310 & & 0.264 & \\
\hline Exchange rates & & 3,573 & 5,590 & 5.74 & 1,285 & 8.02 \\
\hline Coeff. of variation (weighted) & & 0.626 & 0.747 & & 0.692 & \\
\hline Low income $(64)$ & 39.87 & & & & & \\
\hline PPP & & 5,485 & 10,520 & 8.28 & 2,241 & 11.29 \\
\hline Coeff. of variation (weighted) & & 0.385 & 0.309 & & 0.413 & \\
\hline Exchange rates & & 1,017 & 1,950 & 1.97 & 0.372 & 3.24 \\
\hline Coeff. of variation (weighted) & & 0.328 & 0.277 & & 0.372 & \\
\hline \multicolumn{7}{|l|}{ World totals (229) } \\
\hline PPP & & 26,421 & 43,628 & & 9,186 & \\
\hline Coeff. of variation (weighted) & & 1.498 & 1.298 & & 1.093 & \\
\hline Exchange rates & & 20,551 & 33,893 & & 6,205 & \\
\hline Coeff. of variation (weighted) & & 2.141 & 1.878 & & 1.769 & \\
\hline
\end{tabular}

Note: all figures are in year 2000 US\$. Figures are weighted by country population. 
Table 9: Wealth shares for countries with wealth distribution data, official exchange rate basis

\begin{tabular}{|c|c|c|c|c|c|c|c|c|c|c|c|c|c|c|c|c|c|c|c|}
\hline \multirow[b]{2}{*}{ Country } & \multirow[b]{2}{*}{ Year } & \multirow[b]{2}{*}{ Unit } & \multicolumn{11}{|c|}{ share of lowest } & \multicolumn{6}{|c|}{ share of top } \\
\hline & & & $10 \%$ & $20 \%$ & $25 \%$ & $30 \%$ & $40 \%$ & $50 \%$ & $60 \%$ & $70 \%$ & $75 \%$ & $80 \%$ & $90 \%$ & $10 \%$ & $5 \%$ & $2 \%$ & $1 \%$ & $0.5 \%$ & $0.1 \%$ \\
\hline Australia & 2002 & household & 0.0 & 0.0 & & 1.0 & 4.0 & 9.0 & 16.0 & 25.0 & & 38.0 & 56.0 & 45.0 & 32.0 & & & & \\
\hline Canada & 1999 & family unit & & & & & & & & & & & 47.0 & 53.0 & & & & & \\
\hline China & 2002 & person & 0.7 & 2.8 & & 5.8 & 9.6 & 14.4 & 20.6 & 29.0 & & 40.7 & 58.6 & 41.4 & & & & & \\
\hline Denmark & 1975 & household & & & & & & & & & & & 35.0 & 65.0 & 48.0 & & 25.0 & & \\
\hline Finland & 1998 & household & -0.9 & -0.9 & & -0.3 & 2.2 & 7.4 & 15.0 & 25.0 & & 38.6 & 57.7 & 42.3 & & & & & \\
\hline France & 1994 & person? & & & & & & & & & & & 39.0 & 61.0 & & & 21.3 & & 6.3 \\
\hline Germany & 1998 & household & -0.3 & -0.2 & & 0.3 & 1.5 & 3.9 & 9.0 & 18.9 & & 34.0 & 55.7 & 44.4 & & & & & \\
\hline India & $2002-$ & household & 0.2 & 1.0 & & 2.5 & 4.8 & 8.1 & 12.9 & 19.8 & & 30.1 & 47.1 & 52.9 & 38.3 & & 15.7 & & \\
\hline Indonesia & 1997 & household & 0.0 & 0.4 & & 1.3 & 2.8 & 5.1 & 8.5 & 13.5 & & 21.1 & 34.6 & 65.4 & 56.0 & & 28.7 & & \\
\hline Ireland & 1987 & household & 0.0 & 0.2 & & 2.5 & 6.6 & 12.2 & 18.9 & 28.5 & & 40.4 & 57.7 & 42.3 & 28.7 & & 10.4 & & \\
\hline Italy & 2000 & household & & & & & 7.0 & & & & & 36.2 & 51.5 & 48.5 & 36.4 & & 17.2 & & \\
\hline Japan & 1999 & household & 0.5 & 2.1 & & 4.8 & 8.7 & 13.9 & 20.7 & 29.8 & & 42.3 & 60.7 & 39.3 & & & & & \\
\hline Korea, South & 1988 & household & 0.5 & 1.8 & & 4.0 & 7.4 & 12.3 & 18.9 & 27.9 & & 39.9 & 56.9 & 43.1 & 31.0 & & 14.0 & & \\
\hline New Zealand & 2001 & tax unit & & & & & & & & & & & 48.3 & 51.7 & & & & & \\
\hline Norway & 2000 & household & 0.1 & 0.7 & & 2.6 & 5.8 & 10.4 & 16.4 & 24.2 & & 34.6 & 49.6 & 50.5 & & & & & \\
\hline Spain & 2002 & household & & & 2.1 & & & 13.2 & & & 34.7 & & 58.1 & 41.9 & & & & & \\
\hline Sweden & 2002 & household & -5.7 & -6.8 & & -6.9 & -6.6 & -4.8 & -0.6 & 7.1 & & 19.9 & 41.4 & 58.6 & & & & & \\
\hline Switzerland & 1997 & family & & & & & & & & & & & 28.7 & 71.3 & 58.0 & & 34.8 & 27.6 & 16.0 \\
\hline UK & 2000 & adult & & & & & & 5.0 & & & 25.0 & & 44.0 & 56.0 & 44.0 & 31.0 & 23.0 & & \\
\hline USA & 2001 & family & & & & & & 2.8 & & & & & 30.2 & 69.8 & 57.7 & & 32. & & \\
\hline
\end{tabular}


Table 10a: Global wealth distribution in 2000, official exchange rate basis

\begin{tabular}{|c|c|c|c|c|c|c|c|c|c|c|c|c|c|c|c|c|}
\hline & Decile1 & ecile2 & ecile3 [ & ecile4 [ & ecile5 & ecile6 & ecile7 I & ecile8 & Decile9 & Top10 & Top5 & Top1 & $\begin{array}{r}\text { Adult pop. } \\
(000 \mathrm{~s})\end{array}$ & Pop. Share & $\begin{array}{r}\text { Wealth } \\
\text { per adult }\end{array}$ & $\begin{array}{r}\text { Wealth } \\
\text { share }\end{array}$ \\
\hline World wealth shares & 0.03 & 0.09 & 0.2 & 0.3 & 0.5 & 0.8 & 1.4 & 2.8 & 8.8 & 85.1 & 70.6 & 39.9 & & & & \\
\hline Minimum wealth & 0 & 192 & 464 & 890 & 1405 & 2161 & 3517 & 6318 & 14169 & 61041 & 50145 & 14512 & & & & \\
\hline \multicolumn{17}{|l|}{ Population proportions by region } \\
\hline North America & 0.2 & 0.5 & 0.9 & 1.2 & 1.8 & 2.8 & 4.5 & 8.0 & 14.1 & 27.1 & 28.6 & 39.1 & 225719 & 6.1 & 190653 & 34.3 \\
\hline Latin America and Caribbean & 5.5 & 6.7 & 6.9 & 5.7 & 6.2 & 7.9 & 10.2 & 13.2 & 14.7 & 5.0 & 3.1 & 2.1 & 302915 & 8.2 & 18163 & 4.4 \\
\hline Europe & 8.6 & 8.3 & 9.2 & 7.9 & 8.8 & 10.4 & 12.8 & 16.8 & 30.1 & 36.1 & 35.7 & 26.2 & 550579 & 14.9 & 67232 & 29.5 \\
\hline Asia: China & 6.8 & 14.6 & 16.9 & 36.9 & 40.8 & 38.0 & 35.5 & 29.1 & 8.9 & 0.2 & 0.0 & 0.0 & 842063 & 22.8 & 3885 & 2.6 \\
\hline Asia: India & 27.3 & 27.5 & 27.3 & 19.4 & 16.5 & 14.8 & 11.4 & 7.4 & 2.5 & 0.2 & 0.0 & 0.0 & 570595 & 15.4 & 1989 & 0.9 \\
\hline Asia: high income & 0.0 & 0.0 & 0.1 & 0.2 & 0.4 & 0.7 & 1.6 & 3.8 & 12.0 & 26.3 & 29.5 & 31.0 & 166532 & 4.5 & 172414 & 22.9 \\
\hline Asia: other & 24.1 & 24.7 & 24.4 & 19.3 & 17.4 & 17.7 & 16.6 & 14.8 & 12.2 & 2.5 & 1.2 & 0.6 & 642421 & 17.4 & 5952 & 3.1 \\
\hline Africa & 27.3 & 17.5 & 14.1 & 9.2 & 7.8 & 7.4 & 7.0 & 6.4 & 4.4 & 0.7 & 0.3 & 0.2 & 376292 & 10.2 & 3558 & 1.1 \\
\hline Oceania & 0.2 & 0.2 & 0.3 & 0.3 & 0.3 & 0.2 & 0.4 & 0.4 & 1.2 & 2.0 & 1.5 & 0.8 & 20405 & 0.6 & 72874 & 1.2 \\
\hline World & 100 & 100 & 100 & 100 & 100 & 100 & 100 & 100 & 100 & 100 & 100 & 100 & 3697518 & 100 & 33893 & 100 \\
\hline
\end{tabular}


Table 10b: Global wealth distribution in 2000 , selected country details, official exchange rate basis

Decile1 Decile2 Decile3 Decile4 Decile5 Decile6 Decile7 Decile8 Decile9 Top10 Top5 Top1 Adult pop. Pop. Wealth per Wealth Gini

\begin{tabular}{|c|c|c|c|c|c|c|c|c|c|c|c|c|c|c|c|c|c|}
\hline USA & 0.2 & 0.5 & 0.9 & 1.2 & 1.7 & 2.6 & 4.2 & 7.1 & 11.6 & 24.9 & 26.7 & 37.4 & 202865 & 5.5 & 201319 & 32.6 & 0.801 \\
\hline Japan & & & & & & 0.1 & 0.4 & 1.3 & 5.0 & 20.5 & 25.1 & 26.8 & 100933 & 2.7 & 227600 & 18.3 & 0.547 \\
\hline Germany & 1.4 & 0.8 & 0.9 & 0.4 & 0.9 & 0.5 & 0.4 & 1.0 & 3.6 & 7.6 & 9.8 & 3.7 & 64810 & 1.8 & 109735 & 5.7 & 0.671 \\
\hline Italy & & & & & & 0.1 & 0.3 & 1.1 & 4.4 & 6.6 & 5.0 & 3.9 & 46416 & 1.3 & 122250 & 4.5 & 0.609 \\
\hline UK & & & 0.1 & 0.1 & 0.2 & 0.4 & 0.9 & 1.7 & 2.5 & 5.9 & 7.8 & 6.3 & 43871 & 1.2 & 169617 & 5.9 & 0.697 \\
\hline France & & & 0.1 & 0.1 & 0.2 & 0.4 & 0.8 & 1.8 & 4.3 & 4.2 & 4.1 & 5.2 & 44358 & 1.2 & 114650 & 4.1 & 0.730 \\
\hline Spain & & & & 0.1 & 0.1 & 0.3 & 0.5 & 0.7 & 3.0 & 3.9 & 2.5 & 1.3 & 32165 & 0.9 & 86958 & 2.2 & 0.565 \\
\hline Canada & & & & & 0.1 & 0.1 & 0.3 & 0.9 & 2.5 & 2.2 & 1.9 & 1.7 & 22764 & 0.6 & 95606 & 1.7 & 0.663 \\
\hline Australia & & 0.1 & 0.2 & 0.2 & 0.2 & 0.1 & 0.2 & 0.2 & 0.8 & 1.8 & 1.3 & 0.7 & 13690 & 0.4 & 94712 & 1.0 & 0.622 \\
\hline China, Taiwan & & & & & & 0.1 & 0.3 & 0.5 & 1.5 & 1.8 & 1.5 & 1.2 & 15476 & 0.4 & 105613 & 1.3 & 0.654 \\
\hline Korea, South & & & 0.1 & 0.1 & 0.3 & 0.4 & 0.7 & 1.6 & 4.2 & 1.7 & 0.6 & 0.5 & 33242 & 0.9 & 41777 & 1.1 & 0.579 \\
\hline Netherlands & & & & & & 0.1 & 0.1 & 0.3 & 1.0 & 1.7 & 1.7 & 1.5 & 12046 & 0.3 & 144406 & 1.4 & 0.649 \\
\hline Brazil & 1.9 & 2.7 & 2.3 & 2.0 & 2.2 & 2.9 & 3.6 & 4.4 & 4.5 & 1.5 & 0.9 & 0.6 & 104213 & 2.8 & 15958 & 1.3 & 0.783 \\
\hline Mexico & 0.4 & 0.8 & 1.2 & 0.8 & 1.0 & 1.3 & 1.9 & 2.8 & 3.6 & 1.2 & 0.8 & 0.5 & 56132 & 1.5 & 23305 & 1.0 & 0.748 \\
\hline Argentina & 0.1 & 0.2 & 0.3 & 0.4 & 0.3 & 0.5 & 0.6 & 1.0 & 1.9 & 1.0 & 0.7 & 0.5 & 23307 & 0.6 & 40225 & 0.7 & 0.740 \\
\hline Switzerland & & & & & & & 0.1 & 0.3 & 0.5 & 0.6 & 0.7 & 1.3 & 5497 & 0.1 & 222641 & 1.0 & 0.803 \\
\hline Turkey & 0.2 & 0.6 & 1.0 & 0.7 & 0.8 & 1.1 & 1.5 & 2.2 & 2.2 & 0.6 & 0.3 & 0.1 & 40391 & 1.1 & 16218 & 0.5 & 0.717 \\
\hline China & 6.8 & 14.6 & 16.9 & 36.9 & 40.8 & 38.0 & 35.5 & 29.1 & 8.9 & 0.2 & & & 842063 & 22.8 & 3885 & 2.6 & 0.550 \\
\hline India & 27.3 & 27.5 & 27.3 & 19.4 & 16.5 & 14.8 & 11.4 & 7.4 & 2.5 & 0.2 & & & 570595 & 15.4 & 1989 & 0.9 & 0.669 \\
\hline Russia & 3.8 & 3.5 & 3.5 & 3.1 & 3.2 & 3.7 & 3.9 & 2.8 & 1.5 & 0.1 & 0.1 & & 107493 & 2.9 & 4140 & 0.4 & 0.698 \\
\hline Thailand & 0.7 & 1.4 & 1.1 & 1.0 & 1.1 & 1.3 & 1.5 & 1.6 & 1.0 & 0.1 & & & 40160 & 1.1 & 6717 & 0.2 & 0.709 \\
\hline Indonesia & 7.7 & 5.9 & 5.6 & 4.0 & 3.2 & 2.8 & 2.7 & 0.6 & 0.9 & 0.1 & 0.1 & & 124446 & 3.4 & 2421 & 0.2 & 0.763 \\
\hline Nigeria & 5.9 & 3.0 & 2.1 & 1.1 & 0.6 & 0.5 & 0.4 & 0.2 & 0.1 & & & & 51431 & 1.4 & 862 & 0.0 & 0.735 \\
\hline Pakistan & 2.5 & 3.0 & 3.1 & 2.6 & 2.3 & 2.2 & 1.0 & 1.0 & 0.6 & & & & 67968 & 1.8 & 2633 & 0.1 & 0.697 \\
\hline Bangladesh & 2.4 & 2.9 & 3.0 & 2.4 & 2.2 & 2.1 & 1.6 & 1.0 & 0.4 & & & & 66483 & 1.8 & 2424 & 0.1 & 0.658 \\
\hline Viet Nam & 2.3 & 2.0 & 2.0 & 1.6 & 1.3 & 1.1 & 0.8 & 0.5 & 0.2 & & & & 44025 & 1.2 & 1986 & 0.1 & 0.680 \\
\hline World & 100 & 100 & 100 & 100 & 100 & 100 & 100 & 100 & 100 & 100 & 100 & 100 & 3697518 & 100 & 33893 & 100 & 0.892 \\
\hline
\end{tabular}

Note: blank cells indicate values less than 0.05 per cent. 
Table 11a: Global wealth distribution in 2000, PPP values

\begin{tabular}{|c|c|c|c|c|c|c|c|c|c|c|c|c|c|c|c|c|}
\hline & Decile1 & Decile2 & Decile3 & Decile4 & Decile5 & Decile6 & Decile7 & Decile8 & Decile9 T & Top10 & Top5 & Top1 & $\begin{array}{r}\text { dult popn } \\
\text { (000s) }\end{array}$ & $\begin{array}{l}\text { Popn } \\
\text { share }\end{array}$ & $\begin{array}{c}\text { Wealth } \\
\text { per adult }\end{array}$ & $\begin{array}{r}\text { Wealth } \\
\text { share }\end{array}$ \\
\hline World wealth shares & 0.1 & 0.3 & 0.6 & 1.1 & 1.6 & 2.4 & 3.7 & 6.2 & 12.9 & 71.1 & 57.0 & 31.6 & & & & \\
\hline Minimum wealth & 2 & 826 & 1978 & 3693 & 5724 & 8399 & 12749 & 20299 & $35954 \varepsilon$ & 880351 & 70467 & 523264 & & & & \\
\hline \multicolumn{17}{|c|}{ Population proportions by region } \\
\hline North America & 1.4 & 2.6 & 3.5 & 3.3 & 3.5 & 4.0 & 5.2 & 6.2 & 9.6 & 21.6 & 25.7 & 39.3 & 225719 & 6.1 & 193147 & 27.0 \\
\hline Latin America and Caribbean & 10.3 & 9.1 & 8.1 & 6.8 & 6.7 & 7.5 & 8.2 & 9.0 & 9.3 & 6.9 & 6.4 & 6.1 & 302915 & 8.2 & 34956 & 6.6 \\
\hline Europe & 9.1 & 9.2 & 10.1 & 9.1 & 9.3 & 12.0 & 14.1 & 18.1 & 22.7 & 35.0 & 35.8 & 31.2 & 550579 & 14.9 & 81890 & 27.9 \\
\hline Asia: China & 6.8 & 14.3 & 14.8 & 33.5 & 37.5 & 34.2 & 32.4 & 29.4 & 20.7 & 4.1 & 1.4 & 0.0 & 842063 & 22.8 & 16749 & 8.7 \\
\hline Asia: India & 21.0 & 21.9 & 25.2 & 18.1 & 16.3 & 15.8 & 14.2 & 11.6 & 8.0 & 2.3 & 1.2 & 0.0 & 570595 & 15.4 & 11655 & 4.1 \\
\hline Asia: high income & 0.0 & 0.3 & 0.9 & 1.2 & 1.5 & 2.0 & 2.4 & 5.0 & 12.1 & 19.6 & 21.0 & 17.1 & 166532 & 4.5 & 138750 & 14.3 \\
\hline Asia: other & 22.2 & 24.1 & 23.1 & 18.7 & 17.5 & 17.7 & 17.2 & 15.0 & 11.9 & 6.4 & 4.9 & 3.7 & 642421 & 17.4 & 18266 & 7.3 \\
\hline Africa & 28.7 & 17.9 & 14.0 & 9.1 & 7.3 & 6.6 & 6.1 & 5.3 & 4.6 & 2.2 & 1.7 & 1.2 & 376292 & 10.2 & 11730 & 2.7 \\
\hline Oceania & 0.4 & 0.5 & 0.4 & 0.2 & 0.3 & 0.2 & 0.2 & 0.3 & 1.0 & 1.9 & 2.0 & 1.4 & 20405 & 0.6 & 99634 & 1.3 \\
\hline World & 100 & 100 & 100 & 100 & 100 & 100 & 100 & 100 & 100 & 100 & 100 & 100 & 3697519 & 100 & 43628 & 100 \\
\hline
\end{tabular}


Table 11b: Global wealth distribution in 2000, PPP values: selected country details

Adult pop. Pop. Wealth per Wealth

\begin{tabular}{|c|c|c|c|c|c|c|c|c|c|c|c|c|c|c|c|c|c|}
\hline & Decile1 & ecile2 & ecile3 & ecile4 & Decile5 & Decile6 & Decile7 & Decile8 & ecile9 & Гop10 & Top5 & Top1 & (000s) & share & adult & share & Gin \\
\hline$\overline{U S A}$ & 1.4 & 2.6 & 3.4 & 3.1 & 3.3 & 3.6 & 4.6 & 5.3 & 8.1 & 19.6 & 23.5 & 36.8 & 202865 & 5.5 & 201319 & 25.3 & 0.801 \\
\hline Japan & & 0.1 & 0.3 & 0.6 & 0.6 & 0.8 & 0.9 & 2.5 & 7.3 & 14.2 & 15.9 & 11.7 & 100933 & 2.7 & 157146 & 9.8 & 0.547 \\
\hline Germany & 3.0 & 1.2 & 0.8 & 0.4 & 0.1 & 0.7 & 1.1 & 1.5 & 1.9 & 7.0 & 8.9 & 3.9 & 64810 & 1.8 & 114185 & 4.6 & 0.671 \\
\hline UK & 0.1 & 0.3 & 0.5 & 0.6 & 0.7 & 0.9 & 0.7 & 1.2 & 0.8 & 5.9 & 6.0 & 6.3 & 43871 & 1.2 & 172461 & 4.7 & 0.697 \\
\hline Italy & & & 0.1 & 0.2 & 0.3 & 0.5 & 0.9 & 1.7 & 3.1 & 5.8 & 5.5 & 5.3 & 46416 & 1.3 & 148843 & 4.3 & 0.609 \\
\hline China & 6.8 & 14.3 & 14.8 & 33.5 & 37.5 & 34.2 & 32.4 & 29.4 & 20.7 & 4.1 & 1.4 & & 842063 & 22.8 & 16749 & 8.7 & 0.550 \\
\hline Spain & & 0.1 & 0.3 & 0.3 & 0.4 & 0.5 & 0.3 & 0.7 & 2.5 & 3.7 & 3.2 & 2.3 & 32165 & 0.9 & 116782 & 2.3 & 0.565 \\
\hline France & 0.1 & 0.3 & 0.5 & 0.6 & 0.7 & 0.9 & 1.2 & 1.7 & 2.6 & 3.5 & 3.9 & 5.6 & 44358 & 1.2 & 125254 & 3.4 & 0.730 \\
\hline Brazil & 3.9 & 3.1 & 2.8 & 2.3 & 2.4 & 2.6 & 2.7 & 2.9 & 3.0 & 2.4 & 2.3 & 2.3 & 104213 & 2.8 & 35188 & 2.3 & 0.783 \\
\hline India & 21.0 & 21.9 & 25.2 & 18.1 & 16.3 & 15.8 & 14.2 & 11.6 & 8.0 & 2.3 & 1.2 & & 570595 & 15.4 & 11655 & 4.1 & $0.66 \mathrm{~s}$ \\
\hline Canada & & 0.1 & 0.1 & 0.2 & 0.2 & 0.4 & 0.6 & 0.9 & 1.6 & 2.0 & 2.2 & 2.5 & 22764 & 0.6 & 120326 & 1.7 & 0.663 \\
\hline Korea, South & & 0.2 & 0.4 & 0.4 & 0.5 & 0.7 & 0.9 & 1.5 & 2.7 & 1.8 & 1.1 & 0.9 & 33242 & 0.9 & 64521 & 1.3 & 0.579 \\
\hline China, Taiwan & & & 0.1 & 0.1 & 0.2 & 0.3 & 0.3 & 0.5 & 1.0 & 1.7 & 1.8 & 1.9 & 15476 & 0.4 & 143405 & 1.4 & 0.65 \\
\hline Australia & 0.2 & 0.3 & 0.2 & & 0.2 & 0.1 & 0.1 & 0.2 & 0.8 & 1.7 & 1.7 & 1.2 & 13690 & 0.4 & 126635 & 1.1 & 0.622 \\
\hline Russia & 2.9 & 3.0 & 2.9 & 2.7 & 2.6 & 3.1 & 3.5 & 3.8 & 3.0 & 1.5 & 1.0 & 0.9 & 107493 & 2.9 & 24011 & 1.6 & 0.698 \\
\hline Netherlands & & & 0.1 & 0.1 & 0.1 & 0.2 & 0.2 & 0.4 & 0.8 & 1.4 & 1.6 & 1.7 & 12046 & 0.3 & 158484 & 1.2 & $0.64 c$ \\
\hline Mexico & 1.4 & 1.7 & 1.4 & 1.2 & 1.2 & 1.4 & 1.7 & 1.9 & 2.0 & 1.4 & 1.3 & 1.2 & 56132 & 1.5 & 38324 & 1.3 & 0.748 \\
\hline Turkey & 0.5 & 1.1 & 0.9 & 0.8 & 0.9 & 1.1 & 1.3 & 1.5 & 1.6 & 1.1 & 0.9 & 0.8 & 40391 & 1.1 & 40202 & 1.0 & 0.717 \\
\hline Argentina & 0.4 & 0.5 & 0.4 & 0.4 & 0.4 & 0.5 & 0.6 & 0.8 & 1.1 & 1.0 & 1.0 & 0.9 & 23307 & 0.6 & 60917 & 0.9 & 0.740 \\
\hline Indonesia & 6.7 & 4.9 & 5.1 & 3.7 & 3.4 & 3.0 & 2.9 & 2.2 & 0.7 & 0.9 & 0.7 & 0.7 & 124446 & 3.4 & 13401 & 1.0 & 0.763 \\
\hline Thailand & 1.0 & 1.4 & 1.2 & 1.1 & 1.0 & 1.1 & 1.2 & 1.2 & 1.1 & 0.5 & 0.4 & 0.2 & 40160 & 1.1 & 22678 & 0.6 & 0.709 \\
\hline Switzerland & & & & 0.1 & 0.1 & 0.1 & 0.2 & 0.2 & 0.3 & 0.4 & 0.6 & 1.0 & 5497 & 0.1 & 187998 & 0.6 & 0.803 \\
\hline Pakistan & 2.0 & 2.8 & 2.8 & 2.3 & 2.3 & 2.1 & 1.7 & 0.9 & 0.9 & 0.4 & 0.3 & 0.2 & 67968 & 1.8 & 13214 & 0.6 & 0.697 \\
\hline Bangladesh & 1.9 & 2.7 & 2.6 & 2.2 & 2.1 & 2.1 & 1.9 & 1.4 & 0.9 & 0.3 & 0.2 & 0.2 & 66483 & 1.8 & 12389 & 0.5 & 0.658 \\
\hline Viet Nam & 2.0 & 1.9 & 1.9 & 1.5 & 1.2 & 1.2 & 1.0 & 0.7 & 0.5 & 0.1 & 0.1 & & 44025 & 1.2 & 10066 & 0.3 & 0.680 \\
\hline Nigeria & 7.6 & 2.9 & 1.6 & 0.6 & 0.4 & 0.3 & 0.2 & 0.1 & 0.1 & & & & 51431 & 1.4 & 2194 & 0.1 & 0.735 \\
\hline WORLD & 100 & 100 & 100 & 100 & 100 & 100 & 100 & 100 & 100 & 100 & 100 & 100 & 3697519 & 100 & 43628 & 100 & 0.802 \\
\hline
\end{tabular}

Note: Blank cells indicate values less than 0.05 per cent. 
Table 12: Global wealth distribution under alternative assumptions

\begin{tabular}{|c|c|c|c|c|c|c|c|c|c|c|c|c|c|c|c|c|c|c|}
\hline & & $\begin{array}{l}\text { Number } \\
\text { countries }\end{array}$ & \multicolumn{2}{|c|}{$\begin{array}{l}\text { Adult Share of global } \\
\text { population } \\
\text { adult population } \\
(\%)\end{array}$} & $\begin{array}{r}\text { ealth per } \\
\text { adult }\end{array}$ & $\begin{array}{r}\text { ff global } \\
\text { wealth } \\
(\%) \\
\end{array}$ & Quintile1 & \multicolumn{2}{|c|}{ Quintile2 } & \multicolumn{2}{|c|}{ Quintile3 } & \multicolumn{2}{|c|}{ Quintile4 } & Quintile5 & Top10 & Top5 & Top1 & Gini \\
\hline (1) & All countries, official exchange rates & 228 & 3697518 & 100 & 33893 & 100 & 0. & 1 & 0.5 & & .3 & & 1.2 & 93.9 & 85.1 & 70.6 & 39.9 & 0.892 \\
\hline (2) & All countries, PPP valuations & 228 & 3697519 & 100 & 43628 & 100 & 0. & 4 & 1.7 & & .0 & & .9 & 84.0 & 71.1 & 57.0 & 31.6 & 0.802 \\
\hline \multicolumn{19}{|c|}{ Excluding regional average imputations for: } \\
\hline (3) & — average wealth level & 150 & 3540759 & 95.8 & 34960 & 98.8 & 0. & 1 & 0.5 & & .3 & & 1.2 & 93.7 & 84.7 & 70.1 & 39.6 & 0.890 \\
\hline (4) & — wealth distribution & 144 & 3596803 & 97.3 & 34356 & 98.6 & 0. & 1 & 0.5 & & .3 & & 1.2 & 93.8 & 85.0 & 70.5 & 39.9 & 0.891 \\
\hline (5) & — average wealth level and distribution & 129 & 3491133 & 94.4 & 35281 & 98.3 & 0. & 1 & 0.5 & & .3 & & 1.2 & 93.8 & 84.7 & 70.1 & 39.5 & 0.890 \\
\hline \multicolumn{19}{|c|}{ Countries with wealth distribution data } \\
\hline (6) & — using reported wealth distributions & 20 & 2171089 & 58.7 & 48295 & 83.7 & 0. & & 0.5 & & .1 & & 3.9 & 94.4 & 82.8 & 67.0 & 37.4 & 0.887 \\
\hline (7) & - imputing from income distributions & 20 & 2171089 & 58.7 & 48295 & 83.7 & 0. & & 0.3 & & .0 & & 1.9 & 93.7 & 80.5 & 63.9 & 32.8 & 0.879 \\
\hline
\end{tabular}


Figure 1: Net worth from household balance sheet versus disposable income, official exchange rates

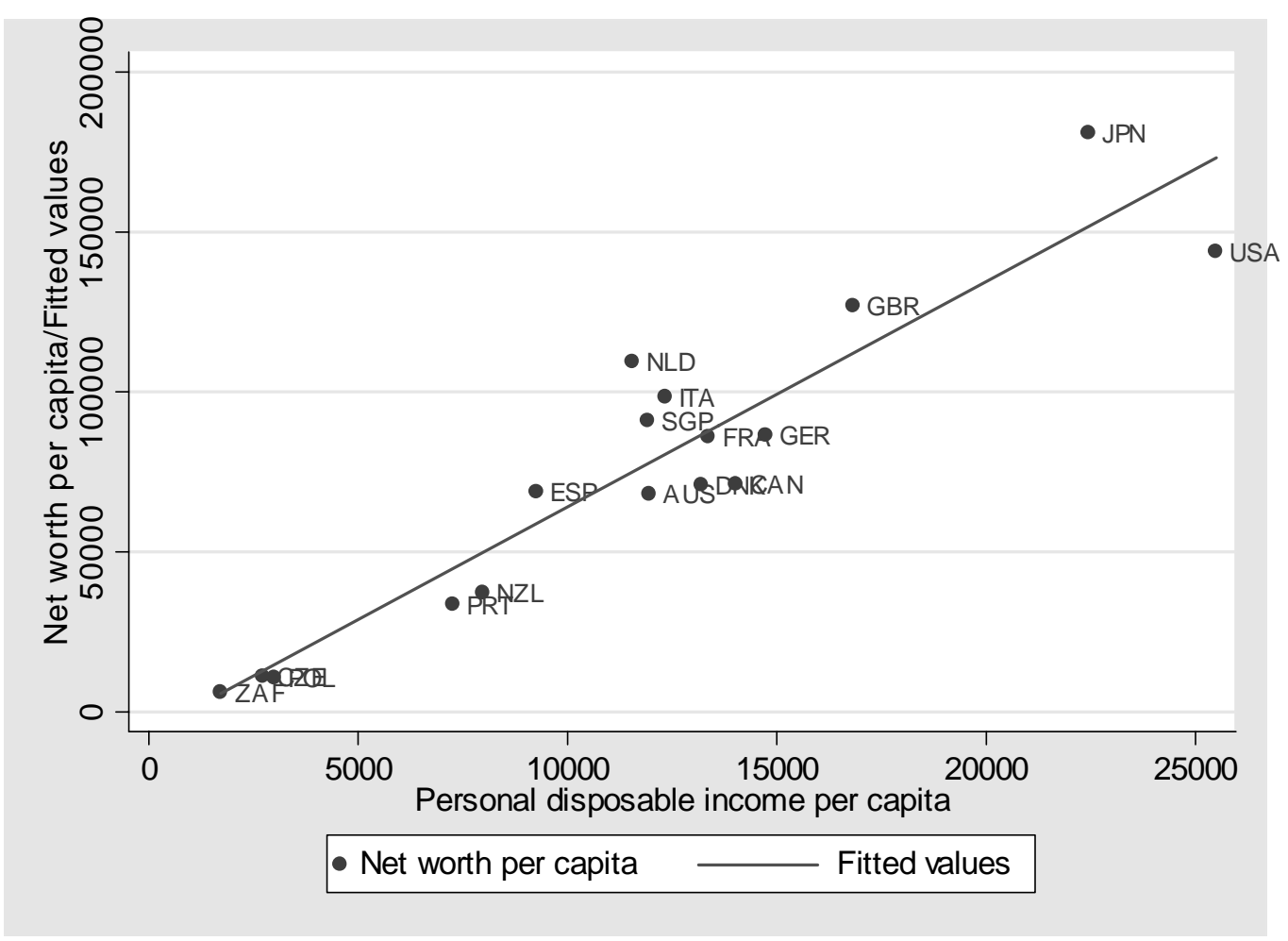


Figure 2: Net worth from surveys versus disposable income, official exchange rates

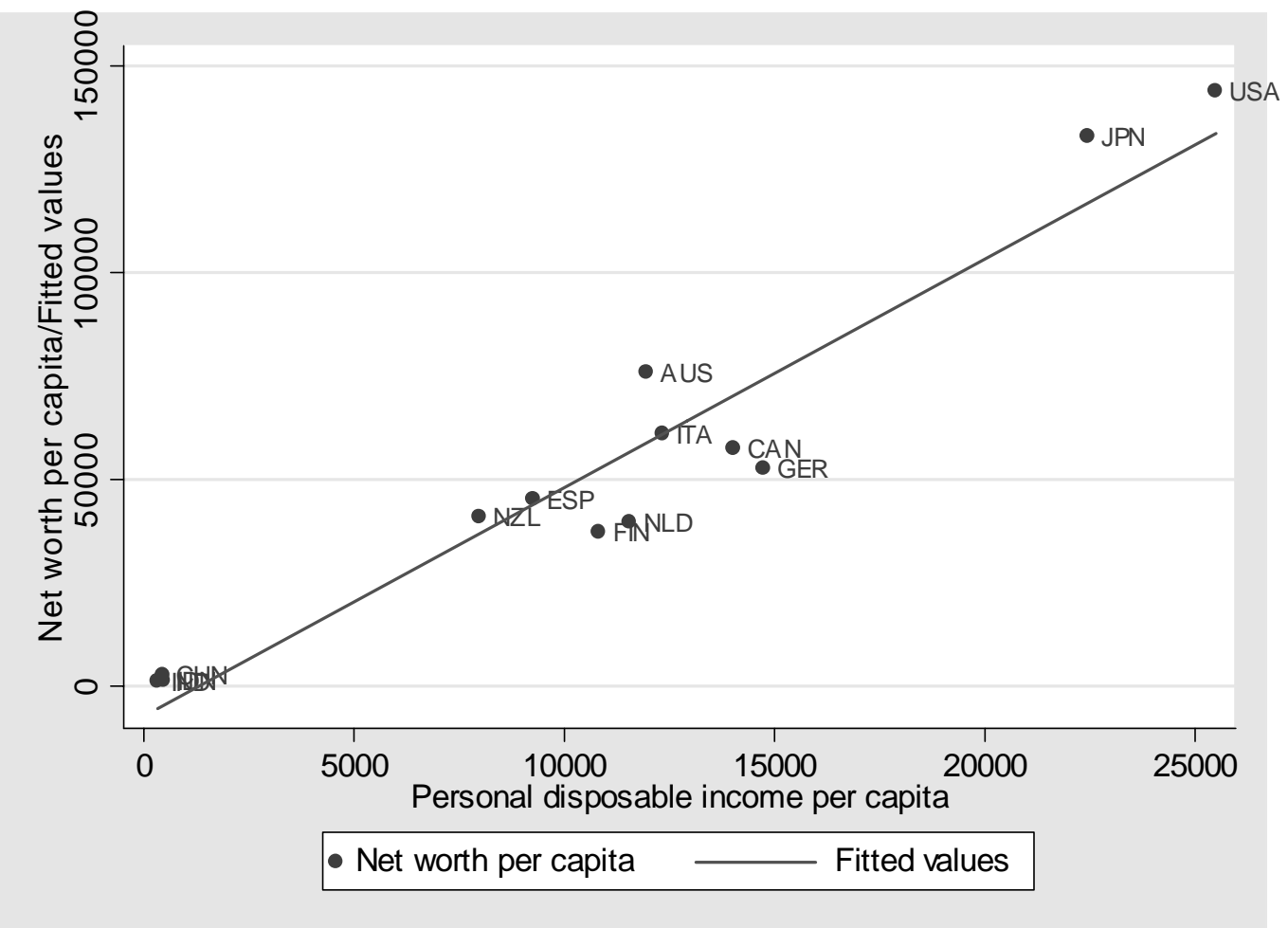


Figure 3: Pareto graph, top tail of estimated world distribution of wealth

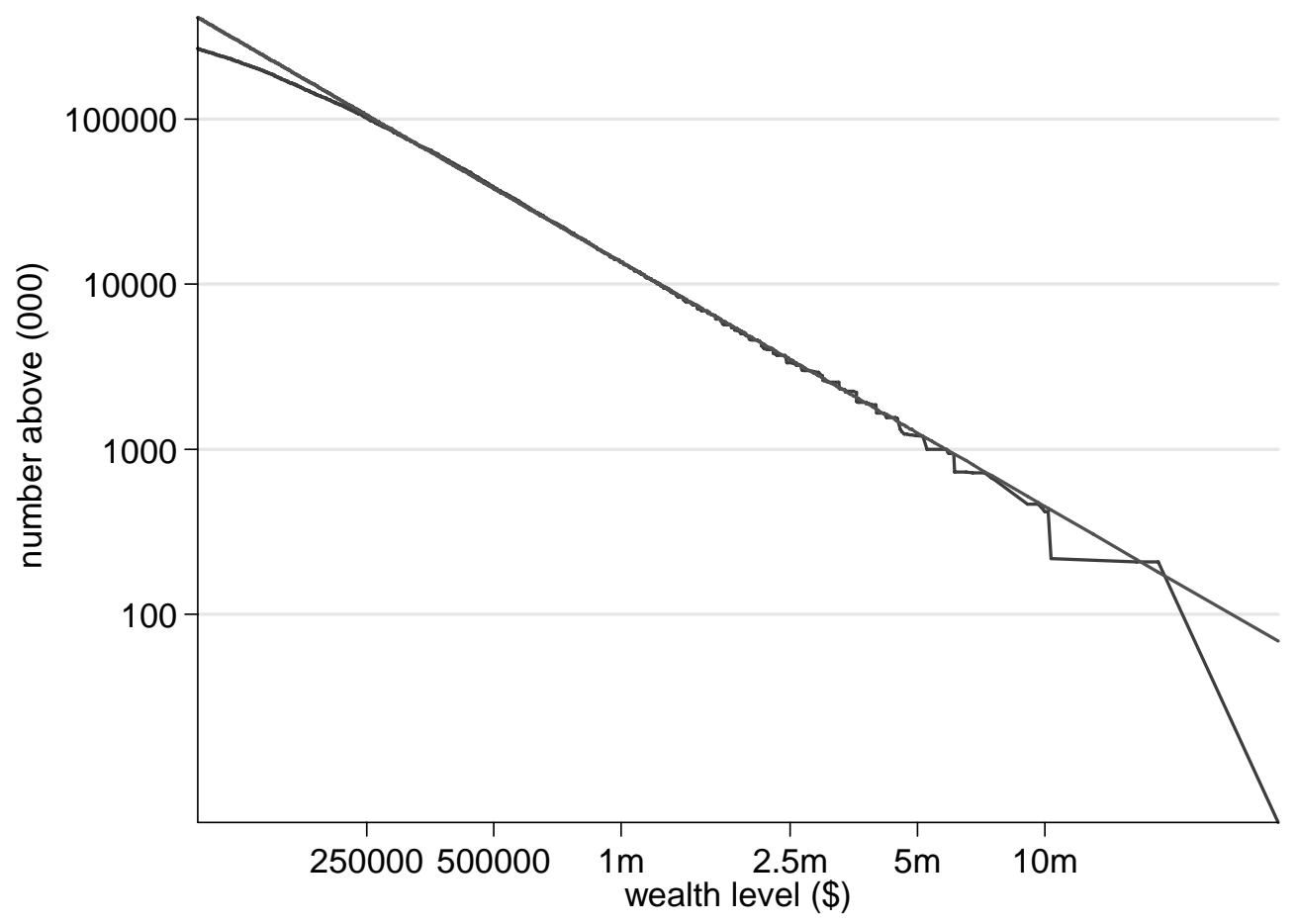




\section{Appendix I: Household Balance Sheet (HBS) Data: Methods}

There is considerable variation between countries in how household balance sheets are constructed, who puts them together, sectoral definition, and asset coverage. In some countries, for example Australia, the UK, and France the balance sheets, or at least their major elements, are compiled as part of the System of National Accounts (SNA). Elsewhere, for example the US, Canada and Japan, they are assembled together with Flow of Funds (FOF) data. In other cases central banks or national statistical agencies issue HBS data independent of the SNA or FOF. The OECD publishes the financial balance sheet of the household sector for its member countries (OECD, 2005). ${ }^{1}$ As discussed below, however, fully comparable household balance sheets including non-financial assets are available for only a subset of OECD countries.

What is important is not who delivers the HBS data, but who and what are covered, and how the data are constructed. The objective is to estimate the balance sheet of the household sector as of a certain date- often but not always the year-end. This can be done by trying to measure the relevant stocks, or by updating previous stock figures by adding estimates of subsequent flows. Both stocks and flows can be measured by direct or indirect means (Aron et al. 2006). In the direct approach data are collected from household members through sample surveys, censuses or administrative records. In the indirect approach the values for the household sector by asset type are calculated as residuals from independent totals by deducting the estimated holdings of other sectors. Often the independent totals are counterpart data, for example the liabilities of the banking sector in the form of deposits. In most countries a mix of direct and indirect approaches is used.

In the United States, for example, most categories of financial assets and liabilities are calculated using the indirect approach (Board of Governors of the Federal Reserve System 2003). That is, amounts held or owed by the other sectors are subtracted from known totals and the remainders are assumed to be the amounts held by the household sector. For consumer credit no deductions are necessary. When micro-data are available, assets and liability totals for the household sector are reviewed in light of that data and sometimes adjusted accordingly. The Survey of Consumer Finances (SCF), which is conducted every three years by the Federal Reserve Board, is used for this purpose. House values and equity in unincorporated business are estimated using the perpetual inventory method. Land values are updated based on an index of land prices.

\footnotetext{
1 Financial balance sheets for the household sector have also been published for eight countries in 'New Europe' by a financial group based in Italy. See UniCredit Group (2005). The countries covered are Bulgaria, Croatia, Czech Republic, Hungary, Poland, Romania, Slovakia, and Turkey. We were only able to obtain nonfinancial data for the Czech Republic, and so it is the only one of these countries whose balance sheet numbers are reported here.
} 
In the United Kingdom, financial assets are measured mostly using the residual approach based on data from banks and other financial intermediaries. Ordinary shares are estimated with the help of a sample survey, the Share Registers Survey, whereas unlisted company shares are estimated using the estate multiplier method. Data on life assurance and pensions funds are obtained from returns made by insurance companies and pension funds. The value of fixed assets is derived using a number of sources. Some of the net capital stock estimates included in non-financial assets are calculated using the perpetual inventory method (Aron et al. 2006). Residential housing stock estimates are compiled using property tax records of local authorities, and farm land and buildings are estimated from data on farm sizes and prices from the Ministry of Agriculture, Fisheries and Food.

Also in Italy, financial assets are measured using the residual approach and are based on data from banks, credit institutions, insurance companies etc. (Brandolini et al. 2004). Debts comprise all short and long term liabilities and are estimated using the same approach. The stock of dwellings is based on a series provided by the Italian Statistics Office given at constant rather than market prices. The series is corrected to be expressed in market prices using a housing price series based on information assembled in a semiannual survey of real estate agents. Benchmark values of the stock of dwellings and the share owned by households are obtained using census data. Apart from housing assets, only durables are included in fixed assets. The stock of durables is computed using the perpetual inventory method.

Sectoral definitions unfortunately are not the same across all countries. Sometimes the household sector only includes households. However, in many cases, as we see below, unincorporated business is included in the household sector; it is also common to include non-profit organizations (NPOs) that serve the household sector. Households are the owners of unincorporated business. In principle this means that whether unincorporated business is included with households or not should not affect estimates of the total wealth of households. ${ }^{2}$ However, where these sectors are separated, unincorporated businesses are in practice treated as having some net worth of their own. Hence households will tend to appear wealthier where the sectors are combined. Apparent composition of household wealth will also be affected. Where the sectors are combined, business assets and debts are separated into the various relevant categories. But where unincorporated business is treated as a separate sector, we will just see a single entry, business equity, in the household balance sheet.

2 If unincorporated business is treated as a separate sector, household wealth will include equity in unincorporated business. 


\section{Appendix II}

\begin{tabular}{|c|c|c|c|c|}
\hline \multicolumn{5}{|c|}{ A. Household Balance Sheet and Financial Balance Sheet Sources } \\
\hline Country & Financial data & Non-financial data & Data combined by & Link to data \\
\hline Australia & $\begin{array}{l}\text { Australian Bureau of Statistics (2005). } 5204.0 \\
\text { Australian System of National Accounts Table } 51 .\end{array}$ & Same as for financial data & & $\begin{array}{l}\text { http://www.abs.gov.au/AUSSTATS/abs@.nsf/Detail } \\
\text { sPage/5204.02004-05?OpenDocument }\end{array}$ \\
\hline Austria & $\begin{array}{l}\text { OECD (2005). Source OECD National Accounts } \\
\text { Statistics. National Accounts of OECD Countries: } \\
\text { Volume IIlb - Financial Balance Sheets - Stocks } \\
\text { Vol } 2005 \text { release } 02 .\end{array}$ & & & \\
\hline Belgium & $\begin{array}{l}\text { OECD (2005). Source OECD National Accounts } \\
\text { Statistics. National Accounts of OECD Countries: } \\
\text { Volume IIIb - Financial Balance Sheets - Stocks } \\
\text { Vol } 2005 \text { release } 02 .\end{array}$ & & & \\
\hline Bulgaria & $\begin{array}{l}\text { UniCredit Group, 'New Europe Household Wealth } \\
\text { Monitor', November } 2005 .\end{array}$ & & & \\
\hline Canada & $\begin{array}{l}\text { Statistics Canada, National Balance Sheet } \\
\text { Accounts 2000; CanSim Matrix } 0751 .\end{array}$ & Same as for financial data & & \\
\hline $\begin{array}{l}\text { China, } \\
\text { Taiwan }\end{array}$ & $\begin{array}{l}\text { National Wealth Statistics. Statistical Tables. } \\
\text { Table 7. (Quoted from Central Bank Flow of Funds } \\
\text { Statistics) }\end{array}$ & $\begin{array}{l}\text { National Wealth Statistics. } \\
\text { Statistical Tables. Table } 7 .\end{array}$ & National Statistical Office & $\begin{array}{l}\text { http://eng.stat.gov.tw/lp.asp?ctNode=1640\&CtUnit= } \\
\text { 789\&BaseDSD }=7\end{array}$ \\
\hline Croatia & $\begin{array}{l}\text { UniCredit Group, 'New Europe Household Wealth } \\
\text { Monitor', November } 2005 .\end{array}$ & & & \\
\hline $\begin{array}{l}\text { Czech } \\
\text { Republic }\end{array}$ & $\begin{array}{l}\text { Czech Statistical Office (2006). Sector Accounts } \\
\text { Times Series. Table ST01415. }\end{array}$ & Same as for financial data & & $\begin{array}{l}\text { http://dw.czso.cz/pls/rocenka/rocenkavyber.casrady } \\
\text { __sek_en }\end{array}$ \\
\hline Denmark & $\begin{array}{l}\text { Statistics Denmark. National Accounts and } \\
\text { Balance of Payments, Annual National Accounts } \\
\text { ESA95, Balance Sheets for Financial Assetes and }\end{array}$ & $\begin{array}{l}\text { Statistics Denmark. National } \\
\text { Accounts and Balance of } \\
\text { Payments, Annual National }\end{array}$ & Authors & $\begin{array}{l}\text { http://www.statbank.dk/statbank5a/default.asp?w=1 } \\
024\end{array}$ \\
\hline
\end{tabular}




\begin{tabular}{|c|c|c|c|c|}
\hline & Liabilities Table NAT10 & $\begin{array}{l}\text { Accounts ESA95, Fixed Capital } \\
\text { Table Nat14. }\end{array}$ & & \\
\hline Estonia & Eurostat Financial Balance Sheets & & & $\begin{array}{l}\text { http://epp.eurostat.cec.eu.int/portal/page?_pageid=1 } \\
\text { 996,45323734\&_dad=portal\&_schema=PORTAL\&s } \\
\text { creen=welcomeref\&open=/fina/fina_st\&language=e } \\
\text { n\&product=EU_MASTER_financial\&root=EU_MAST } \\
\text { ER_financial\&scrollto=0 }\end{array}$ \\
\hline France & $\begin{array}{l}\text { INSEE. Comptes Nationaux Annuels - Base } 2000 . \\
\text { Table } 4515 .\end{array}$ & Same as for financial data & & $\begin{array}{l}\text { http://www.insee.fr/fr/indicateur/cnat_annu/base_20 } \\
\text { 00/tableaux/comptes_patrimoine.htm }\end{array}$ \\
\hline Germany & $\begin{array}{l}\text { Deutshe Bundesbank (2004). Financial Accounts } \\
\text { for Germany } 1991 \text { to 2003.Special Statistical } \\
\text { Publication. Table XI p. } 86 \text {. }\end{array}$ & $\begin{array}{l}\text { Real assets data provided by } \\
\text { Deutsches Bundesbank. }\end{array}$ & Authors & \\
\hline Greece & Eurostat Financial Balance Sheets & & & see Estonia \\
\hline Hungary & $\begin{array}{l}\text { OECD (2005). Source OECD National Accounts } \\
\text { Statistics. National Accounts of OECD Countries: } \\
\text { Volume IIIb - Financial Balance Sheets - Stocks } \\
\text { Vol } 2005 \text { release } 02 .\end{array}$ & & & \\
\hline Italy & Financial Accounts by the Bank of Italy. & $\begin{array}{l}\text { Adjusted Italian Statistical Office } \\
\text { data. }\end{array}$ & $\begin{array}{l}\text { Brandolini, A., Cannari L., } \\
\text { D'Alession G. and Faiella } \\
\text { I. (2004). Household } \\
\text { Wealth Distribution in Italy } \\
\text { in the } 1990 \text { s. Termi di } \\
\text { discussione No } 530 . \\
\text { Rome: Bank of Italy. } \\
\text { Table 2, p.18. }\end{array}$ & \\
\hline Japan & $\begin{array}{l}\text { Economic Planning Agency, Government of } \\
\text { Japan. Annual Report on National Accounts. Table } \\
4 .\end{array}$ & Same as for financial data & & \\
\hline
\end{tabular}




\begin{tabular}{|c|c|c|c|c|}
\hline Korea & $\begin{array}{l}\text { OECD (2005). Source OECD National Accounts } \\
\text { Statistics. National Accounts of OECD Countries: } \\
\text { Volume IIIb - Financial Balance Sheets - Stocks } \\
\text { Vol } 2005 \text { release } 02 .\end{array}$ & & & \\
\hline Latvia & Eurostat Financial Balance Sheets & & & see Estonia \\
\hline Lithuania & Eurostat Financial Balance Sheets & & & see Estonia \\
\hline Netherlands & $\begin{array}{l}\text { van Els P., van den End W. and van Rooij M. } \\
\text { (2005). Financial Behaviour of Dutch Households: } \\
\text { Analysis of DNB Household Survey Data } 2003 . \\
\text { BIS papers No } 22 \text {. Table } 1 \text { p. } 23 .\end{array}$ & $\begin{array}{l}\text { Statistics Netherlands. Sector } \\
\text { Accounts: Financial Balance } \\
\text { Sheets Table 4b. }\end{array}$ & Authors & $\begin{array}{l}\text { http://www.cbs.nl/NR/exeres/7EA6458D-70C3- } \\
\text { 46B2-83E7-93166787810C }\end{array}$ \\
\hline New Zealand & $\begin{array}{l}\text { Reserve Bank of New Zealand. Household } \\
\text { Financial Assets and Liabilities. }\end{array}$ & Same as for financial data & & $\begin{array}{l}\text { http://www.rbnz.govt.nz/statistics/1834998- } \\
\text { 07.html\#P320_25575 }\end{array}$ \\
\hline Norway & $\begin{array}{l}\text { Bank of Norway (2003). Financial Stability Report } \\
\text { 1/2003. Table } 3.2 \text {. }\end{array}$ & $\begin{array}{l}\text { Bank of Norway. Financial } \\
\text { Accounts of the Household } \\
\text { Sector. Table } 1 .\end{array}$ & Authors & $\begin{array}{l}\text { http://www.norges-bank.no/front/rapport/en/fs/2003- } \\
\text { 01/ http://www.norges- } \\
\text { bank.no/front/statistikk/en/husholdningene/ }\end{array}$ \\
\hline Poland & $\begin{array}{l}\text { OECD (2005). Source OECD National Accounts } \\
\text { Statistics. National Accounts of OECD Countries: } \\
\text { Volume IIIb - Financial Balance Sheets - Stocks } \\
\text { Vol } 2005 \text { release } 02 \text {. }\end{array}$ & $\begin{array}{l}\text { Yemtsov R: (2006). Housing } \\
\text { Privatization and Household } \\
\text { Wealth in transition. Paper } \\
\text { prepared for the UNU-WIDER } \\
\text { project on "Personal Assets from } \\
\text { a Global Perspective". }\end{array}$ & Authors & \\
\hline Portugal & Financial Accounts by the Bank of Portugal. & $\begin{array}{l}\text { Housing stock estimates } \\
\text { calculated based on data from } \\
\text { the Central Statistical Office and } \\
\text { the Bank of Portugal. }\end{array}$ & $\begin{array}{l}\text { Cardoso F. and da Cunha } \\
\text { V.G. (2005). Household } \\
\text { Wealth in Portugal 1998- } \\
\text { 2004. Bank of Portugal } \\
\text { WP 4-05. Table A1.1, p. } \\
\text { 41. }\end{array}$ & \\
\hline Romania & $\begin{array}{l}\text { UniCredit Group, 'New Europe Household Wealth } \\
\text { Monitor', November } 2005 .\end{array}$ & & & \\
\hline Singapore & $\begin{array}{l}\text { Singapore Department of Statistics (2003): Wealth } \\
\text { and Liabilities of Singapore Households }\end{array}$ & Same as for financial data & & \\
\hline
\end{tabular}




\begin{tabular}{|c|c|c|c|c|}
\hline Slovakia & $\begin{array}{l}\text { UniCredit Group, 'New Europe Household Wealth } \\
\text { Monitor', November } 2005 .\end{array}$ & & & \\
\hline Slovenia & Eurostat Financial Balance Sheets & & & \\
\hline South Africa & $\begin{array}{l}\text { Aron J. and Muellbauer J. (2004). Revised } \\
\text { Estimates of Personal Sector Wealth for South } \\
\text { Africa. CSAE WPS/2004-24. Table 2, p.50. }\end{array}$ & Same as for financial data & & \\
\hline Spain & $\begin{array}{l}\text { Banco de Espana (2005). Financial Accounts of } \\
\text { the Spanish Economy. Table II.5.e. }\end{array}$ & $\begin{array}{l}\text { Banco de Espana. Summary } \\
\text { indicators: Household market } \\
\text { indicators. }\end{array}$ & Authors & $\begin{array}{l}\text { http://www.bde.es/estadis/ccffe/cfcap2e.htm } \\
\text { http://www.bde.es/infoest/sindie.htm }\end{array}$ \\
\hline Sweden & $\begin{array}{l}\text { OECD (2005). Source OECD National Accounts } \\
\text { Statistics. National Accounts of OECD Countries: } \\
\text { Volume IIIb - Financial Balance Sheets - Stocks } \\
\text { Vol } 2005 \text { release } 02 .\end{array}$ & & & \\
\hline Switzerland & $\begin{array}{l}\text { Swiss National Bank. Swiss Financial Accounts. } \\
\text { Table T11. }\end{array}$ & & & $\begin{array}{l}\text { http://www.snb.ch/e/publikationen/publi.html?file=/e/ } \\
\text { publikationen/monatsheft/aktuelle_publikation/html/e } \\
\text { /inhaltsverzeichnis.html }\end{array}$ \\
\hline Turkey & $\begin{array}{l}\text { UniCredit Group, 'New Europe Household Wealth } \\
\text { Monitor', November } 2005 .\end{array}$ & & & \\
\hline UK & $\begin{array}{l}\text { National Statistics Online. Financial Statistics Time } \\
\text { Series Data Table } 12.1 \mathrm{~N} .\end{array}$ & $\begin{array}{l}\text { United Kingdom National } \\
\text { Accounts. Blue Book Time } \\
\text { Series Data Table } 10.10 .\end{array}$ & Authors & $\begin{array}{l}\text { http://www.statistics.gov.uk/STATBASE/Product.asp } \\
\text { ?vlnk=376 } \\
\text { http://www.statistics.gov.uk/STATBASE/Product.asp } \\
\text { ?vlnk=1143 }\end{array}$ \\
\hline USA & $\begin{array}{l}\text { Federal Reserve Statistical Release (2005). Flow } \\
\text { of Funds Accounts of the United States. Release } \\
\text { Z. I, June 9, 2005. Table B.100. }\end{array}$ & Same as for financial data & & http://www.federalreserve.gov/releases/z1/ \\
\hline
\end{tabular}




\begin{tabular}{|lll|}
\hline B. Survey Sources & \\
\hline Australia & 2002 & Household Income, and Labour Dynamics; See Headey, et al (2005). \\
Canada & 1999 & Survey of Financial Security; See Statistics Canada 2001). \\
China & 2002 & China Academy of Social Science Survey; See Renwei and Sing (2005). \\
Denmark & 1975 & Wealth tax records; See Spånt (1982). \\
Finland & 1998 & Household Wealth Survey; See Statistics Finland (2000). \\
France & 1994 & Estate tax returns; See Piketty, et al (2003). \\
Germany & 1998 & Einkommens und verbrauchstichprobe; See Ammermuller et al. (2005). \\
India & 2002 & All-India Debt and Investment Survey (NSS 59th round); See National Sample Survey Organization (2005). \\
Indonesia & 1997 & Indonesia Family Life Survey (own calculations); http://www.rand.org/labor/FLS/IFLS/ \\
Ireland & 1987 & The survey of Income Distribution, Poverty and Usage of State Services; See Nolan (1991). \\
Italy & 2000 & Survey of Household Income and Wealth; See Brandolini et al. (2004). \\
Japan & 1999 & National Survey of Family Income and Expenditure; See Japan Statistics Bureau (2005). \\
Korea & 1988 & Korea Development Institute Survey; See Leipziger et al. (1992). \\
Mexico & 2002 & Encuesta Nacional sobre Niveles de Vida de los Hogares; See Jäntti and Sierminska (2006). \\
New Zealand & 2001 & Household Saving Survey; See Statistics New Zealand (2002). \\
Norway & 2000 & Income and Property Distribution Survey; See Statistics Norway (2005). \\
Spain & 2002 & Survey of Household Finances; See Banco de Espana (2005). \\
Sweden & 2002 & Wealth statistics based on registers of total population; See Statistics Sweden (2004). \\
Switzerland & 1997 & Survey based on county wealth tax statistics; See Dell et al (2005). \\
United Kingdom & 2000 & Inland Revenue Statistics; See Inland Revenue Statistics (2005). \\
United States & 2001 & Survey of Consumer Finances 2001; See Kennickel (2003). \\
\hline
\end{tabular}




\section{Appendix III}

\begin{tabular}{|c|c|c|c|c|c|c|}
\hline \multirow[t]{3}{*}{ Independent variables } & \multicolumn{6}{|c|}{ Dependent variables } \\
\hline & \multicolumn{2}{|c|}{ Log of non-financial wealth } & \multicolumn{2}{|c|}{ Log of financial wealth } & \multicolumn{2}{|c|}{ Log of liabilities } \\
\hline & (1a) & (1b) & (2a) & (2b) & (3a) & (3b) \\
\hline \multirow[t]{2}{*}{ Constant } & .481 & .215 & $-2.626^{*}$ & -3.298 & $-10.784^{\star \star}$ & $-9.71^{* \star}$ \\
\hline & $(.784)$ & $(.477)$ & $(1.397)$ & $(.805)$ & $(.875)$ & $(.688)$ \\
\hline \multirow[t]{2}{*}{ Log of disp. income per capita } & $1.092^{\star \star}$ & $1.076^{* \star}$ & $1.246^{\star *}$ & $1.252^{\star \star}$ & $1.683^{\star *}$ & $1.501^{* *}$ \\
\hline & $(.068)$ & $(.049)$ & $(.161)$ & $(.118)$ & $(.137)$ & $(.103)$ \\
\hline \multirow[t]{2}{*}{ Log of population density } & .0821 & $.085^{\star}$ & & & & \\
\hline & $(.036)$ & $(.036)$ & & & & \\
\hline \multirow[t]{2}{*}{ Log of market cap. rate } & & & $.441^{\star \star}$ & $.472^{\star *}$ & & \\
\hline & & & $(.132)$ & $(.102)$ & & \\
\hline \multirow[t]{2}{*}{ Log of pensions as a \% of GDP } & & & -.146 & & & \\
\hline & & & $(.148)$ & & & \\
\hline Log of domestic credits & & & & & $.934^{\star \star}$ & $1.070^{\star *}$ \\
\hline available to the private sector & & & & & $(.172)$ & $(.158)$ \\
\hline \multirow[t]{2}{*}{ Income Gini } & -.012 & & -.007 & & & \\
\hline & $(.008)$ & & $(.017)$ & & & \\
\hline \multirow[t]{2}{*}{ Survey dummy } & .197 & & $-.941^{*}$ & $-1.387^{* *}$ & -.407 & \\
\hline & $(.196)$ & & $(.410)$ & $(.340)$ & $(.407)$ & \\
\hline $\mathrm{R}^{2}$ & .9662 & .9598 & & & & \\
\hline "R ${ }^{2 n}$ & & & .9458 & .9565 & 0.9545 & 0.9521 \\
\hline RMSE & .280 & .289 & .410 & .452 & .495 & .540 \\
\hline Sample Size & 23 & 23 & 29 & 33 & 29 & 33 \\
\hline
\end{tabular}

Note: The sample for the non-financial regressions consists of 18 countries with HBS data and 5 with survey data. The sample for the financial and liabilities regressions consist of 29 countries with HBS or financial balance sheet data and 4 with survey data. In the non-financial assets regression, Ordinary Least Squares are used. In the financial assets and liabilities regressions, the Seemingly Unrelated Regressions (SUR) estimation method is used. Standard errors in parenthesis. Significance levels: \# -10\% level; ${ }^{*}-5 \%$ level; **-1\% level. 


\section{Appendix IV}

Appendix IV Table 1: Net worth per capita from household balance sheet and survey data, 2000

\begin{tabular}{|c|c|c|c|c|c|c|c|c|}
\hline Country & $\begin{array}{l}\text { Net worth } \\
\text { per capita }^{\mathrm{a}}\end{array}$ & $\begin{array}{l}\text { Real GDP } \\
\text { per capita }^{c}\end{array}$ & $\begin{array}{r}\text { Personal } \\
\text { disposable } \\
\text { income per } \\
\text { capita }^{\mathrm{d}}\end{array}$ & $\begin{array}{l}\text { Real cons. } \\
\text { per capita }^{c}\end{array}$ & $\begin{array}{l}\text { Net worth } \\
\text { per capita }^{a}\end{array}$ & $\begin{array}{l}\text { Real GDP } \\
\text { per capita }^{c}\end{array}$ & $\begin{array}{r}\text { Personal } \\
\text { disposable } \\
\text { income per } \\
\text { capita }^{\mathrm{d}} \\
\end{array}$ & $\begin{array}{r}\text { Real } \\
\text { cons. per } \\
\text { capita }^{\mathrm{c}} \\
\end{array}$ \\
\hline \multicolumn{9}{|l|}{ PPP } \\
\hline \multicolumn{5}{|c|}{ Household balance sheet data } & \multicolumn{4}{|l|}{ Survey data } \\
\hline Australia & 90,906 & 27,193 & 15,983 & 18,913 & 101,597 & 27,193 & 15,983 & 18,913 \\
\hline Canada & 89,252 & 28,731 & 17,661 & 15,994 & 72,384 & 28,731 & 17,661 & 15,994 \\
\hline China & & & & & 11,267 & 5,796 & 3,849 & 3,937 \\
\hline China, Taiwan & 100,009 & 19,714 & na & 12,603 & & & & \\
\hline Czech Republic & 32,431 & 14,844 & 8,557 & 10,008 & & & & \\
\hline Denmark & 66,191 & 28,539 & 12,348 & 17,951 & & & & \\
\hline Finland & & & & & 38,754 & 24,416 & 11,285 & 15,197 \\
\hline France & 93,729 & 23,614 & 14,732 & 15,672 & & & & \\
\hline Germany & 89,871 & 23,917 & 15,486 & 16,603 & 52,794 & 23,917 & 15,486 & 16,603 \\
\hline India & & & & & 6,513 & 2,684 & 1,916 & 1,406 \\
\hline Indonesia & & & & & 7,973 & 4,035 & 2,603 & 2,614 \\
\hline Italy & 119,704 & 22,876 & 15,169 & 14,195 & 74,217 & 22,876 & 15,169 & 14,195 \\
\hline Japan & 124,858 & 25,924 & 15,496 & 15,975 & 91,856 & 25,924 & 15,496 & 15,975 \\
\hline Netherlands & 120,086 & 25,759 & 12,798 & 16,159 & 43,434 & 25,759 & 12,798 & 16,159 \\
\hline New Zealand & 55,823 & 20,008 & 12,034 & 13,534 & 61,872 & 20,008 & 12,034 & 13,534 \\
\hline Poland & 24,654 & 9,661 & 7,190 & 6,493 & & & & \\
\hline Portugal & 53,357 & 17,089 & 11,700 & 10,380 & & & & \\
\hline Singapore & 113,631 & 28,644 & 14,885 & 9,965 & & & & \\
\hline South Africa & 16,266 & 8,017 & 4,691 & 5,210 & & & & \\
\hline Spain & 92,253 & 19,037 & 12,544 & 13,160 & 60,614 & 19,037 & 12,544 & 13,160 \\
\hline UK & 128,959 & 24,252 & 17,102 & 18,238 & & & & \\
\hline USA & 143,727 & 35,619 & 25,480 & 24,313 & 143,857 & 35,619 & 25,480 & 24,313 \\
\hline \multicolumn{9}{|l|}{ Exchange rates } \\
\hline \multicolumn{5}{|c|}{ Household balance sheet data } & \multicolumn{4}{|l|}{ Survey data } \\
\hline Australia & 67,990 & 20,338 & 11,954 & 14,145 & 75,986 & 20,338 & 11,954 & 14,145 \\
\hline Canada & 70,916 & 22,828 & 14,032 & 12,708 & 57,513 & 22,828 & 14,032 & 12,708 \\
\hline China & & & & & 2,613 & 1,523 & 910 & 1,378 \\
\hline China, Taiwan & 73,654 & 14,519 & na & 9,282 & & & & \\
\hline Czech Republic & 10,797 & 4,942 & 2,732 & 3,332 & & & & \\
\hline Denmark & 70,751 & 30,505 & 13,198 & 19,188 & & & & \\
\hline
\end{tabular}




\begin{tabular}{|c|c|c|c|c|c|c|c|c|}
\hline Finland & & & & & 37,171 & 23,419 & 10,824 & 14,576 \\
\hline France & 85,794 & 21,425 & 13,367 & 14,220 & & & & \\
\hline Germany & 86,369 & 22,758 & 14,735 & 15,799 & 52,744 & 22,758 & 14,735 & 15,799 \\
\hline India & & & & & 1,112 & 458 & 327 & 240 \\
\hline Indonesia & & & & & 1,440 & 729 & 470 & 472 \\
\hline Italy & 98,317 & 18,604 & 12,336 & 11,544 & 60,957 & 18,604 & 12,336 & 11,544 \\
\hline Japan & 180,837 & 37,547 & 22,443 & 23,137 & 133,038 & 37,547 & 22,443 & 23,137 \\
\hline Netherlands & 109,418 & 23,261 & 11,557 & 14,592 & 39,613 & 23,261 & 11,557 & 14,592 \\
\hline New Zealand & 37,026 & 13,271 & 7,982 & 8,976 & 41,038 & 13,271 & 7,982 & 8,976 \\
\hline Poland & 10,438 & 4,090 & 2,999 & 2,749 & & & & \\
\hline Portugal & 33,421 & 10,614 & 7,267 & 6,447 & & & & \\
\hline Singaporee & 90,960 & 22,929 & 11,915 & 7,977 & & & & \\
\hline South Africa & 5,977 & 2,946 & 1,724 & 1,914 & & & & \\
\hline Spain & 68,693 & 14,048 & 9,257 & 9,711 & 45,176 & 14,048 & 9,257 & 9,711 \\
\hline UK & 126,832 & 23,852 & 16,820 & 17,937 & 143,857 & 35,619 & 25,480 & 24,313 \\
\hline USA & 143,727 & 35,619 & 25,480 & 24,313 & & & & \\
\hline
\end{tabular}

Note: all figures are in year 2000 , US\$. ${ }^{a}$ Source for the first panel: flow of funds data, national balance sheets and financial balance sheets augmented with estimates of housing assets. In the third panel the original survey data are from close to year 2000. The numbers have been adjusted by the real growth rate per capita. ${ }^{b}$ Source: Penn World Table 6.1. ${ }^{\mathrm{c}}$ Source: The Economist Intelligence Unit. 


\section{Appendix V}

Appendix V Table 1: The distribution of net worth by country, 2000

\begin{tabular}{|c|c|c|c|c|c|c|c|c|c|c|}
\hline $\begin{array}{l}\text { World Bank country group and } \\
\text { country }\end{array}$ & $\begin{array}{r}\text { Percent of } \\
\text { world } \\
\text { population }\end{array}$ & $\begin{array}{r}\text { Share of } \\
\text { adult } \\
\text { population }\end{array}$ & $\begin{array}{r}\text { Net worth } \\
\text { per capita } \\
(\mathrm{PPP})\end{array}$ & $\begin{array}{r}\text { Net worth } \\
\text { per capita } \\
\text { (exchange } \\
\text { rates) }\end{array}$ & $\begin{array}{r}\text { Percent of } \\
\text { world net } \\
\text { worth (PPP) }\end{array}$ & $\begin{array}{r}\text { Percent of } \\
\text { world net } \\
\text { worth } \\
\text { (exchange } \\
\text { rates) }\end{array}$ & $\begin{array}{r}\text { Real GDP } \\
\text { per capita } \\
(\mathrm{PPP})\end{array}$ & $\begin{array}{r}\text { Real GDP } \\
\text { per capita } \\
\text { (exchange } \\
\text { rates) }\end{array}$ & $\begin{array}{r}\text { Percent of } \\
\text { world GDP } \\
\text { (PPP) }\end{array}$ & $\begin{array}{r}\text { Percent of } \\
\text { world GDP } \\
\text { (exchange } \\
\text { rates) }\end{array}$ \\
\hline \multicolumn{11}{|l|}{ High income: OECD } \\
\hline Australia & 0.31 & 71.78 & 90,906 & 67,990 & 1.08 & 1.04 & 27,193 & 20,338 & 1.13 & 1.21 \\
\hline Austria & 0.13 & 77.46 & 66,639 & 62,420 & 0.34 & 0.40 & 24,836 & 23,264 & 0.44 & 0.59 \\
\hline Belgium & 0.17 & 76.63 & 85,818 & 76,577 & 0.55 & 0.63 & 25,008 & 22,315 & 0.56 & 0.72 \\
\hline Canada & 0.50 & 74.18 & 89,252 & 70,916 & 1.70 & 1.74 & 28,731 & 22,828 & 1.91 & 2.18 \\
\hline Denmark & 0.09 & 76.26 & 66,191 & 70,751 & 0.22 & 0.30 & 28,539 & 30,505 & 0.33 & 0.51 \\
\hline Finland & 0.09 & 75.44 & 38,754 & 37,171 & 0.12 & 0.15 & 24,416 & 23,419 & 0.27 & 0.38 \\
\hline France & 0.97 & 74.83 & 93,729 & 85,794 & 3.46 & 4.07 & 23,614 & 21,425 & 3.04 & 3.95 \\
\hline Germany & 1.35 & 78.71 & 89,871 & 86,369 & 4.60 & 5.69 & 23,917 & 22,758 & 4.28 & 5.83 \\
\hline Greece & 0.18 & 78.07 & 72,825 & 50,240 & 0.50 & 0.44 & 15,558 & 10,733 & 0.37 & 0.37 \\
\hline Iceland & 0.00 & 69.12 & 73,401 & 83,031 & 0.01 & 0.02 & 26,929 & 30,461 & 0.02 & 0.03 \\
\hline Ireland & 0.06 & 69.59 & 89,327 & 82,555 & 0.21 & 0.25 & 27,197 & 25,135 & 0.22 & 0.30 \\
\hline Italy & 0.95 & 80.42 & 119,704 & 98,317 & 4.30 & 4.54 & 22,876 & 18,604 & 2.87 & 3.34 \\
\hline Japan & 2.09 & 79.45 & 124,858 & 180,837 & 9.86 & 18.37 & 25,924 & 37,547 & 7.15 & 14.84 \\
\hline Korea, South & 0.77 & 71.06 & 45,849 & 29,687 & 1.33 & 1.11 & 14,937 & 9,671 & 1.52 & 1.41 \\
\hline Luxembourg & 0.01 & 75.42 & 182,567 & 160,030 & 0.05 & 0.06 & 48,968 & 42,923 & 0.05 & 0.06 \\
\hline Netherlands & 0.26 & 75.77 & 120,086 & 109,418 & 1.19 & 1.39 & 25,759 & 23,261 & 0.89 & 1.15 \\
\hline New Zealand & 0.06 & 70.14 & 55,823 & 37,026 & 0.13 & 0.11 & 20,008 & 13,271 & 0.17 & 0.16 \\
\hline Norway & 0.07 & 74.12 & 72,254 & 81,188 & 0.20 & 0.29 & 32,057 & 36,021 & 0.31 & 0.50 \\
\hline Portugal & 0.17 & 77.05 & 53,357 & 33,421 & 0.34 & 0.27 & 17,089 & 10,614 & 0.38 & 0.34 \\
\hline Spain & 0.67 & 79.00 & 92,253 & 68,693 & 2.34 & 2.24 & 19,037 & 14,048 & 1.68 & 1.78 \\
\hline Sweden & 0.15 & 75.87 & 80,091 & 83,918 & 0.44 & 0.60 & 24,628 & 25,805 & 0.47 & 0.71 \\
\hline Switzerland & 0.12 & 76.69 & 144,186 & 170,755 & 0.64 & 0.98 & 28,209 & 33,407 & 0.44 & 0.74 \\
\hline UK & 0.96 & 74.78 & 128,959 & 126,832 & 4.71 & 5.95 & 24,252 & 23,852 & 3.09 & 4.35 \\
\hline USA & 4.67 & 71.39 & 143,727 & 143,727 & 25.40 & 32.65 & 35,619 & 35,619 & 21.97 & 31.49 \\
\hline
\end{tabular}




\begin{tabular}{|c|c|c|c|c|c|c|c|c|c|c|}
\hline \multicolumn{11}{|l|}{ High income: nonOECD } \\
\hline Andorra & 0.00 & 77.20 & 99,526 & 90,277 & 0.00 & 0.00 & & 13,785 & & 0.00 \\
\hline Anguilla & 0.00 & 67.75 & 76,364 & 53,813 & 0.00 & 0.00 & & 9,481 & & 0.00 \\
\hline Antigua and Barbuda & 0.00 & 68.20 & 20,565 & 11,577 & 0.00 & 0.00 & 18,007 & 10,137 & 0.00 & 0.00 \\
\hline Aruba & 0.00 & 67.75 & 76,364 & 53,813 & 0.00 & 0.00 & & 19,922 & & 0.01 \\
\hline Bahamas & 0.00 & 60.87 & 76,364 & 53,813 & 0.01 & 0.01 & 16,793 & 14,217 & 0.01 & 0.01 \\
\hline Bahrain & 0.01 & 63.93 & 105,287 & 130,833 & 0.04 & 0.07 & 15,870 & 11,775 & 0.02 & 0.02 \\
\hline Barbados & 0.00 & 71.27 & 103,787 & 58,121 & 0.02 & 0.01 & 17,526 & 9,815 & 0.01 & 0.01 \\
\hline Bermuda & 0.00 & 71.66 & 138,417 & 136,630 & 0.01 & 0.01 & & 42,533 & & 0.01 \\
\hline British Virgin Islands & 0.00 & 67.75 & 76,364 & 53,813 & 0.00 & 0.00 & & 34,849 & & 0.00 \\
\hline Brunei Darussalam & 0.01 & 60.06 & 105,287 & 130,833 & 0.02 & 0.03 & & 12,922 & & 0.01 \\
\hline Cayman Islands & 0.00 & 67.75 & 76,364 & 53,813 & 0.00 & 0.00 & & 36,912 & & 0.00 \\
\hline Channel Islands & 0.00 & 77.11 & 99,526 & 90,277 & 0.01 & 0.01 & & & & \\
\hline China, Hong Kong & 0.11 & 76.61 & 202,189 & 173,353 & 0.83 & 0.92 & 27,893 & 23,915 & 0.40 & 0.49 \\
\hline China, Macao & 0.10 & 69.74 & 73,072 & 44,794 & 0.28 & 0.22 & 23,118 & 14,172 & 0.31 & 0.27 \\
\hline China, Taiwan & 0.01 & 69.74 & 100,009 & 73,654 & 0.03 & 0.03 & 19,714 & 14,519 & 0.02 & 0.02 \\
\hline Cyprus & 0.01 & 69.46 & 99,526 & 90,277 & 0.05 & 0.06 & 17,107 & 11,259 & 0.03 & 0.03 \\
\hline Faeroe Islands & 0.00 & 77.20 & 99,526 & 90,277 & 0.00 & 0.00 & & & & \\
\hline Falkland Islands & 0.00 & 67.73 & 76,364 & 53,813 & 0.00 & 0.00 & & & & \\
\hline French Polynesia & 0.00 & 58.67 & 85,054 & 62,825 & 0.01 & 0.01 & 24,624 & 14,132 & 0.01 & 0.01 \\
\hline Gibraltar & 0.00 & 77.20 & 99,526 & 90,277 & 0.00 & 0.00 & & & & \\
\hline Greenland & 0.00 & 71.66 & 138,417 & 136,630 & 0.00 & 0.01 & & & & \\
\hline Guadeloupe & 0.01 & 67.10 & 76,364 & 53,813 & 0.02 & 0.02 & & 10,030 & & 0.01 \\
\hline Guam & 0.00 & 61.69 & 85,054 & 62,825 & 0.01 & 0.01 & & & & \\
\hline Isle of Man & 0.00 & 77.20 & 99,526 & 90,277 & 0.00 & 0.01 & & & & \\
\hline Israel & 0.36 & 63.05 & 64,034 & 59,207 & 0.88 & 1.05 & 19,148 & 17,705 & 0.92 & 1.22 \\
\hline Kuwait & 0.04 & 66.88 & 105,287 & 130,833 & 0.15 & 0.23 & 15,743 & 15,947 & 0.08 & 0.11 \\
\hline Liechtenstein & 0.00 & 77.20 & 99,526 & 90,277 & 0.00 & 0.00 & & & & \\
\hline Malta & 0.01 & 72.46 & 75,694 & 40,471 & 0.02 & 0.01 & 18,256 & 9,761 & 0.02 & 0.01 \\
\hline Martinique & 0.01 & 69.09 & 76,364 & 53,813 & 0.02 & 0.02 & & 10,664 & & 0.01 \\
\hline Monaco & 0.00 & 77.20 & 99,526 & 90,277 & 0.00 & 0.00 & & 22,065 & & 0.00 \\
\hline Montserrat & 0.00 & 67.75 & 76,364 & 53,813 & 0.00 & 0.00 & & 8,916 & & 0.00 \\
\hline Netherlands Antilles & 0.00 & 67.98 & 76,364 & 53,813 & 0.01 & 0.01 & & 12,862 & & 0.01 \\
\hline New Caledonia & 0.00 & 61.44 & 85,054 & 62,825 & 0.01 & 0.01 & 22,193 & 12,455 & 0.01 & 0.01 \\
\hline
\end{tabular}




\begin{tabular}{|c|c|c|c|c|c|c|c|c|c|c|}
\hline Puerto Rico & 0.06 & 68.03 & 75,582 & 54,362 & 0.18 & 0.17 & 22,242 & 15,998 & 0.19 & 0.19 \\
\hline Qatar & 0.01 & 67.09 & 105,287 & 130,833 & 0.04 & 0.06 & & 30,558 & & 0.06 \\
\hline Saint-Pierre et Miquelon & 0.00 & 71.67 & 138,417 & 136,630 & 0.00 & 0.00 & & & & \\
\hline San Marino & 0.00 & 77.20 & 99,526 & 90,277 & 0.00 & 0.00 & & 29,039 & & 0.00 \\
\hline Singapore & 0.07 & 71.94 & 113,631 & 90,960 & 0.28 & 0.29 & 28,644 & 22,929 & 0.25 & 0.29 \\
\hline Slovenia & 0.03 & 77.35 & 36,672 & 19,713 & 0.04 & 0.03 & 16,983 & 9,130 & 0.07 & 0.06 \\
\hline Turks and Caicos Islands & 0.00 & 67.75 & 76,364 & 53,813 & 0.00 & 0.00 & & 10,938 & & 0.00 \\
\hline United Arab Emirates & 0.05 & 68.76 & 105,287 & 130,833 & 0.21 & 0.34 & & 18,906 & & 0.19 \\
\hline US Virgin Islands & 0.00 & 65.59 & 76,364 & 53,813 & 0.01 & 0.00 & & & & \\
\hline Vatican & 0.00 & 77.20 & 99,526 & 90,277 & 0.00 & 0.00 & & & & \\
\hline \multicolumn{11}{|l|}{ Upper middle income } \\
\hline American Samoa & 0.00 & 62.04 & 47,569 & 33,489 & 0.00 & 0.00 & & & & \\
\hline Argentina & 0.61 & 63.17 & 38,481 & 25,410 & 0.88 & 0.75 & 11,729 & 7,745 & 0.94 & 0.89 \\
\hline Belize & 0.00 & 49.27 & 12,318 & 5,851 & 0.00 & 0.00 & 7,170 & 3,406 & 0.00 & 0.00 \\
\hline Botswana & 0.03 & 48.51 & 16,457 & 6,396 & 0.02 & 0.01 & 7,703 & 2,994 & 0.03 & 0.02 \\
\hline Brazil & 2.86 & 59.94 & 21,092 & 9,566 & 2.28 & 1.33 & 7,745 & 3,512 & 2.92 & 1.90 \\
\hline Chile & 0.25 & 63.65 & 30,760 & 13,722 & 0.29 & 0.17 & 10,389 & 4,635 & 0.35 & 0.22 \\
\hline Cook Islands & 0.00 & 62.04 & 47,569 & 33,489 & 0.00 & 0.00 & & 4,413 & & 0.00 \\
\hline Costa Rica & 0.06 & 58.13 & 14,973 & 10,615 & 0.04 & 0.03 & 5,873 & 4,164 & 0.05 & 0.05 \\
\hline Croatia & 0.07 & 76.12 & 22,439 & 10,221 & 0.06 & 0.04 & 9,547 & 4,349 & 0.09 & 0.06 \\
\hline Czech Republic & 0.17 & 76.84 & 32,431 & 10,797 & 0.21 & 0.09 & 14,844 & 4,942 & 0.33 & 0.16 \\
\hline Dominica & 0.00 & 59.29 & 12,552 & 5,625 & 0.00 & 0.00 & 8,284 & 3,712 & 0.00 & 0.00 \\
\hline Estonia & 0.02 & 74.36 & 26,361 & 8,420 & 0.02 & 0.01 & 10,873 & 3,473 & 0.03 & 0.01 \\
\hline French Guiana & 0.00 & 55.21 & 22,932 & 12,424 & 0.00 & 0.00 & & 8,011 & & 0.00 \\
\hline Gabon & 0.02 & 47.42 & 14,539 & 7,491 & 0.01 & 0.01 & 7,780 & 4,008 & 0.02 & 0.02 \\
\hline Grenada & 0.00 & 59.39 & 15,010 & 9,784 & 0.00 & 0.00 & 6,410 & 4,178 & 0.00 & 0.00 \\
\hline Hungary & 0.17 & 76.61 & 32,456 & 13,562 & 0.21 & 0.11 & 11,063 & 4,623 & 0.25 & 0.15 \\
\hline Latvia & 0.04 & 74.57 & 19,162 & 6,951 & 0.03 & 0.01 & 8,305 & 3,013 & 0.04 & 0.02 \\
\hline Lebanon & 0.06 & 59.56 & 20,526 & 12,828 & 0.04 & 0.03 & 6,089 & 3,806 & 0.04 & 0.04 \\
\hline Libya & 0.09 & 53.97 & 17,339 & 6,285 & 0.06 & 0.03 & & 6,484 & & 0.11 \\
\hline Lithuania & 0.06 & 72.80 & 22,126 & 8,076 & 0.05 & 0.02 & 8,397 & 3,065 & 0.06 & 0.03 \\
\hline Malaysia & 0.38 & 56.28 & 15,046 & 6,137 & 0.22 & 0.11 & 9,422 & 3,843 & 0.47 & 0.27 \\
\hline Mauritius & 0.02 & 65.70 & 62,338 & 15,983 & 0.05 & 0.02 & 14,406 & 3,693 & 0.04 & 0.01 \\
\hline Mexico & 1.64 & 56.08 & 21,493 & 13,070 & 1.34 & 1.05 & 9,711 & 5,905 & 2.11 & 1.84 \\
\hline
\end{tabular}




\begin{tabular}{|c|c|c|c|c|c|c|c|c|c|c|}
\hline Northern Mariana Islands & 0.00 & 62.04 & 47,569 & 33,489 & 0.00 & 0.00 & & & & \\
\hline Oman & 0.04 & 53.26 & 18,943 & 11,130 & 0.03 & 0.02 & 12,491 & 7,615 & 0.07 & 0.06 \\
\hline Palau & 0.00 & 62.04 & 47,569 & 33,489 & 0.00 & 0.00 & & 6,150 & & 0.00 \\
\hline Panama & 0.05 & 58.67 & 15,677 & 8,152 & 0.03 & 0.02 & 6,650 & 3,458 & 0.04 & 0.03 \\
\hline Poland & 0.64 & 72.08 & 24,654 & 10,438 & 0.59 & 0.32 & 9,661 & 4,090 & 0.81 & 0.49 \\
\hline Réunion & 0.01 & 62.67 & 17,339 & 6,285 & 0.01 & 0.00 & & 9,014 & & 0.02 \\
\hline Russian Federation & 2.41 & 73.34 & 17,610 & 3,036 & 1.61 & 0.36 & 9,996 & 1,723 & 3.18 & 0.79 \\
\hline Saint Kitts and Nevis & 0.00 & 58.48 & 21,909 & 11,441 & 0.00 & 0.00 & 14,627 & 7,639 & 0.00 & 0.00 \\
\hline Saint Lucia & 0.00 & 57.70 & 17,697 & 11,732 & 0.00 & 0.00 & 6,823 & 4,523 & 0.00 & 0.00 \\
\hline Saudi Arabia & 0.35 & 51.16 & 22,864 & 16,206 & 0.31 & 0.28 & 12,374 & 8,771 & 0.58 & 0.59 \\
\hline Seychelles & 0.00 & 55.42 & 26,034 & 16,904 & 0.00 & 0.00 & 11,644 & 7,561 & 0.00 & 0.00 \\
\hline Slovakia & 0.09 & 72.22 & 23,968 & 6,779 & 0.08 & 0.03 & 12,619 & 3,569 & 0.15 & 0.06 \\
\hline South Africa & 0.75 & 55.86 & 16,266 & 5,977 & 0.46 & 0.22 & 8,017 & 2,946 & 0.79 & 0.42 \\
\hline Trinidad and Tobago & 0.02 & 63.60 & 53,429 & 23,408 & 0.04 & 0.02 & 13,721 & 6,011 & 0.04 & 0.02 \\
\hline Uruguay & 0.05 & 67.60 & 20,207 & 11,807 & 0.04 & 0.03 & 10,285 & 6,009 & 0.07 & 0.06 \\
\hline Venezuela & 0.40 & 56.14 & 14,629 & 10,101 & 0.22 & 0.20 & 7,232 & 4,994 & 0.38 & 0.38 \\
\hline \multicolumn{11}{|l|}{ Lower middle income } \\
\hline Albania & 0.05 & 60.44 & 10,504 & 3,155 & 0.02 & 0.01 & 3,658 & 1,099 & 0.02 & 0.01 \\
\hline Algeria & 0.50 & 53.68 & 7,270 & 2,087 & 0.14 & 0.05 & 6,107 & 1,754 & 0.40 & 0.17 \\
\hline Armenia & 0.05 & 64.44 & 9,545 & 1,548 & 0.02 & 0.00 & 3,068 & 498 & 0.02 & 0.00 \\
\hline Belarus & 0.16 & 73.14 & 14,591 & 1,698 & 0.09 & 0.01 & 8,738 & 1,017 & 0.19 & 0.03 \\
\hline Bolivia & 0.14 & 50.15 & 7,215 & 2,450 & 0.04 & 0.02 & 2,934 & 996 & 0.05 & 0.03 \\
\hline Bosnia and Herzegovina & 0.06 & 73.92 & 12,131 & 2,457 & 0.03 & 0.01 & 5,252 & 1,117 & 0.04 & 0.01 \\
\hline Bulgaria & 0.13 & 77.43 & 15,356 & 3,544 & 0.08 & 0.02 & 6,356 & 1,467 & 0.11 & 0.04 \\
\hline Cape Verde & 0.01 & 44.78 & 10,720 & 3,157 & 0.00 & 0.00 & 4,299 & 1,266 & 0.00 & 0.00 \\
\hline China & 20.57 & 67.27 & 11,267 & 2,613 & 8.77 & 2.62 & 3,844 & 891 & 10.45 & 3.47 \\
\hline Colombia & 0.69 & 57.45 & 14,291 & 4,730 & 0.37 & 0.16 & 5,796 & 1,918 & 0.53 & 0.25 \\
\hline Cuba & 0.18 & 72.09 & 12,086 & 4,587 & 0.08 & 0.04 & & 2,467 & & 0.09 \\
\hline Djibouti & 0.01 & 46.46 & 14,118 & 4,470 & 0.01 & 0.00 & 1,924 & 830 & 0.00 & 0.00 \\
\hline Dominican Republic & 0.14 & 53.99 & 13,729 & 5,713 & 0.07 & 0.04 & 5,654 & 2,352 & 0.10 & 0.06 \\
\hline Ecuador & 0.20 & 55.01 & 6,911 & 1,996 & 0.05 & 0.02 & 3,720 & 1,074 & 0.10 & 0.04 \\
\hline Egypt & 1.11 & 52.83 & 16,650 & 5,754 & 0.70 & 0.31 & 4,406 & 1,523 & 0.64 & 0.32 \\
\hline El Salvador & 0.10 & 53.95 & 18,893 & 8,632 & 0.07 & 0.04 & 4,622 & 2,112 & 0.06 & 0.04 \\
\hline Equatorial Guinea & 0.01 & 45.98 & 7,355 & 2,097 & 0.00 & 0.00 & 10,302 & 2,938 & 0.01 & 0.00 \\
\hline
\end{tabular}




\begin{tabular}{|c|c|c|c|c|c|c|c|c|c|c|}
\hline Fiji & 0.01 & 55.91 & 10,084 & 4,153 & 0.01 & 0.00 & 4,950 & 2,039 & 0.01 & 0.01 \\
\hline Guatemala & 0.18 & 44.65 & 12,769 & 4,934 & 0.09 & 0.04 & 4,335 & 1,675 & 0.11 & 0.06 \\
\hline Guyana & 0.01 & 58.22 & 5,647 & 1,328 & 0.00 & 0.00 & 4,072 & 958 & 0.01 & 0.00 \\
\hline Honduras & 0.11 & 47.09 & 5,523 & 2,356 & 0.02 & 0.01 & 2,164 & 923 & 0.03 & 0.02 \\
\hline Iran & 1.09 & 51.31 & 17,569 & 11,621 & 0.73 & 0.62 & 7,202 & 4,764 & 1.04 & 0.98 \\
\hline Iraq & 0.41 & 46.70 & 12,343 & 3,480 & 0.19 & 0.07 & & 766 & & 0.06 \\
\hline Jamaica & 0.04 & 57.20 & 10,416 & 8,562 & 0.02 & 0.02 & 3,464 & 2,848 & 0.02 & 0.02 \\
\hline Jordan & 0.08 & 49.76 & 12,217 & 4,825 & 0.04 & 0.02 & 4,282 & 1,691 & 0.05 & 0.03 \\
\hline Kazakhstan & 0.25 & 63.24 & 14,281 & 2,119 & 0.13 & 0.03 & 8,331 & 1,236 & 0.27 & 0.06 \\
\hline Kiribati & 0.00 & 52.86 & 10,084 & 4,153 & 0.00 & 0.00 & & 574 & & 0.00 \\
\hline Macedonia & 0.03 & 69.59 & 14,606 & 4,652 & 0.02 & 0.01 & 5,506 & 1,754 & 0.02 & 0.01 \\
\hline Maldives & 0.00 & 44.67 & 12,343 & 3,480 & 0.00 & 0.00 & & 2,146 & & 0.00 \\
\hline Marshall Islands & 0.00 & 52.86 & 10,084 & 4,153 & 0.00 & 0.00 & & 1,910 & & 0.00 \\
\hline Micronesia (Fed. States of) & 0.00 & 47.34 & 10,084 & 4,153 & 0.00 & 0.00 & & 2,138 & & 0.00 \\
\hline Morocco & 0.48 & 55.31 & 13,603 & 3,687 & 0.25 & 0.09 & 4,299 & 1,165 & 0.27 & 0.11 \\
\hline Namibia & 0.03 & 46.14 & 9,219 & 2,742 & 0.01 & 0.00 & 6,058 & 1,802 & 0.02 & 0.01 \\
\hline Nauru & 0.00 & 52.86 & 10,084 & 4,153 & 0.00 & 0.00 & & 2,698 & & 0.00 \\
\hline Niue & 0.00 & 52.85 & 10,084 & 4,153 & 0.00 & 0.00 & & & & \\
\hline Palestinian Territory & 0.05 & 43.37 & 12,343 & 3,480 & 0.02 & 0.01 & & & & \\
\hline Paraguay & 0.09 & 49.41 & 11,101 & 3,163 & 0.04 & 0.01 & 4,801 & 1,368 & 0.06 & 0.02 \\
\hline Peru & 0.43 & 55.29 & 12,234 & 5,328 & 0.20 & 0.11 & 4,799 & 2,090 & 0.27 & 0.17 \\
\hline Philippines & 1.25 & 51.75 & 14,182 & 3,533 & 0.67 & 0.21 & 4,065 & 1,013 & 0.67 & 0.24 \\
\hline Pitcairn & 0.00 & & 10,084 & 4,153 & 0.00 & 0.00 & & & & \\
\hline Romania & 0.36 & 74.29 & 14,827 & 4,821 & 0.20 & 0.09 & 5,024 & 1,634 & 0.24 & 0.11 \\
\hline Saint Helena & 0.00 & 53.70 & 14,118 & 4,470 & 0.00 & 0.00 & & & & \\
\hline Saint Vincent and Grenadines & 0.00 & 55.54 & 13,149 & 4,870 & 0.00 & 0.00 & 7,847 & 2,906 & 0.00 & 0.00 \\
\hline Samoa & 0.00 & 49.30 & 10,084 & 4,153 & 0.00 & 0.00 & 5,096 & 1,363 & 0.00 & 0.00 \\
\hline Serbia and Montenegro & 0.17 & 72.30 & 12,131 & 2,457 & 0.08 & 0.02 & & 1,043 & & 0.03 \\
\hline Sri Lanka & 0.33 & 63.93 & 10,617 & 2,329 & 0.13 & 0.04 & 3,841 & 842 & 0.17 & 0.05 \\
\hline Suriname & 0.01 & 56.77 & 12,086 & 4,587 & 0.00 & 0.00 & & 1,838 & & 0.00 \\
\hline Swaziland & 0.02 & 43.42 & 13,239 & 3,377 & 0.01 & 0.00 & 5,047 & 1,287 & 0.01 & 0.00 \\
\hline Syria & 0.28 & 47.11 & 8,789 & 10,046 & 0.09 & 0.14 & 4,338 & 4,958 & 0.16 & 0.26 \\
\hline Thailand & 1.01 & 65.37 & 14,824 & 4,390 & 0.57 & 0.22 & 6,715 & 1,989 & 0.90 & 0.38 \\
\hline Tokelau & 0.00 & 52.90 & 10,084 & 4,153 & 0.00 & 0.00 & & & & \\
\hline
\end{tabular}




\begin{tabular}{|c|c|c|c|c|c|c|c|c|c|c|}
\hline Tonga & 0.00 & 50.62 & 10,084 & 4,153 & 0.00 & 0.00 & 6,288 & 1,421 & 0.00 & 0.00 \\
\hline Tunisia & 0.16 & 58.95 & 21,237 & 6,042 & 0.13 & 0.05 & 7,130 & 2,029 & 0.15 & 0.06 \\
\hline Turkey & 1.12 & 59.20 & 23,798 & 9,601 & 1.01 & 0.52 & 7,414 & 2,991 & 1.10 & 0.63 \\
\hline Turkmenistan & 0.07 & 53.14 & 12,343 & 3,480 & 0.03 & 0.01 & 3,668 & 1,062 & 0.04 & 0.01 \\
\hline Tuvalu & 0.00 & 52.86 & 10,084 & 4,153 & 0.00 & 0.00 & & 1,409 & & 0.00 \\
\hline Ukraine & 0.81 & 74.46 & 9,890 & 1,236 & 0.30 & 0.05 & 5,147 & 643 & 0.55 & 0.10 \\
\hline Vanuatu & 0.00 & 47.53 & 10,084 & 4,153 & 0.00 & 0.00 & 3,104 & 1,123 & 0.00 & 0.00 \\
\hline Wallis and Futuna Islands & 0.00 & 52.85 & 10,084 & 4,153 & 0.00 & 0.00 & & & & \\
\hline \multicolumn{11}{|l|}{ Low income } \\
\hline Afghanistan & 0.39 & 42.90 & 6,561 & 1,164 & 0.10 & 0.02 & & 101 & & 0.01 \\
\hline Angola & 0.23 & 42.20 & 2,349 & 577 & 0.02 & 0.01 & 1,952 & 737 & 0.06 & 0.03 \\
\hline Azerbaijan & 0.13 & 59.14 & 6,717 & 1,237 & 0.03 & 0.01 & 3,555 & 654 & 0.06 & 0.02 \\
\hline Bangladesh & 2.12 & 51.57 & 6,389 & 1,250 & 0.51 & 0.13 & 1,772 & 347 & 0.50 & 0.14 \\
\hline Benin & 0.12 & 43.24 & 3,370 & 950 & 0.02 & 0.01 & 1,225 & 345 & 0.02 & 0.01 \\
\hline Bhutan & 0.03 & 47.85 & 6,561 & 1,164 & 0.01 & 0.00 & & 234 & & 0.00 \\
\hline Burkina Faso & 0.19 & 40.66 & 2,123 & 419 & 0.01 & 0.00 & 986 & 195 & 0.02 & 0.01 \\
\hline Burundi & 0.11 & 40.20 & 1,876 & 327 & 0.01 & 0.00 & 619 & 108 & 0.01 & 0.00 \\
\hline Cambodia & 0.21 & 45.88 & 4,883 & 753 & 0.04 & 0.01 & 1,859 & 287 & 0.05 & 0.01 \\
\hline Cameroon & 0.24 & 45.90 & 5,272 & 1,262 & 0.05 & 0.01 & 2,301 & 551 & 0.07 & 0.03 \\
\hline Central African Republic & 0.06 & 46.01 & 1,949 & 428 & 0.00 & 0.00 & 1,148 & 252 & 0.01 & 0.00 \\
\hline Chad & 0.13 & 42.61 & 1,728 & 329 & 0.01 & 0.00 & 959 & 183 & 0.02 & 0.00 \\
\hline Comoros & 0.01 & 45.10 & 5,170 & 1,026 & 0.00 & 0.00 & 1,823 & 362 & 0.00 & 0.00 \\
\hline Congo, Democratic Republic & 0.82 & 42.06 & 1,402 & 180 & 0.04 & 0.01 & 669 & 86 & 0.07 & 0.01 \\
\hline Congo, Republic & 0.06 & 42.69 & 2,795 & 1,127 & 0.01 & 0.00 & 2,533 & 1,022 & 0.02 & 0.01 \\
\hline Côte d'Ivoire & 0.27 & 44.99 & 5,502 & 1,589 & 0.06 & 0.02 & 2,028 & 586 & 0.07 & 0.03 \\
\hline Eritrea & 0.06 & 43.66 & 2,349 & 577 & 0.01 & 0.00 & 747 & 203 & 0.01 & 0.00 \\
\hline Ethiopia & 1.13 & 43.81 & 1,414 & 193 & 0.06 & 0.01 & 720 & 98 & 0.11 & 0.02 \\
\hline Gambia & 0.02 & 48.89 & 3,885 & 945 & 0.00 & 0.00 & 1,329 & 323 & 0.00 & 0.00 \\
\hline Georgia & 0.08 & 70.47 & 12,315 & 1,371 & 0.04 & 0.01 & 5,315 & 592 & 0.05 & 0.01 \\
\hline Ghana & 0.33 & 47.41 & 4,129 & 775 & 0.05 & 0.01 & 1,376 & 258 & 0.06 & 0.02 \\
\hline Guinea & 0.14 & 45.96 & 7,734 & 1,062 & 0.04 & 0.01 & 2,961 & 407 & 0.05 & 0.01 \\
\hline Guinea-Bissau & 0.02 & 43.09 & 1,673 & 409 & 0.00 & 0.00 & 738 & 180 & 0.00 & 0.00 \\
\hline Haiti & 0.13 & 47.17 & 6,221 & 1,611 & 0.03 & 0.01 & 1,798 & 466 & 0.03 & 0.01 \\
\hline India & 16.78 & 55.88 & 6,513 & 1,112 & 4.14 & 0.91 & 2,684 & 458 & 5.95 & 1.45 \\
\hline
\end{tabular}




\begin{tabular}{|c|c|c|c|c|c|c|c|c|c|c|}
\hline Indonesia & 3.44 & 59.49 & 7,973 & 1,440 & 1.04 & 0.24 & 4,035 & 729 & 1.83 & 0.47 \\
\hline Kenya & 0.50 & 43.69 & 3,671 & 966 & 0.07 & 0.02 & 1,316 & 346 & 0.09 & 0.03 \\
\hline Korea, North & 0.36 & 65.41 & 6,561 & 1,164 & 0.09 & 0.02 & & 476 & & 0.03 \\
\hline Kyrgyzstan & 0.08 & 54.64 & 5,174 & 433 & 0.02 & 0.00 & 3,205 & 268 & 0.03 & 0.00 \\
\hline Laos & 0.09 & 46.75 & 6,561 & 1,164 & 0.02 & 0.00 & 1,551 & 328 & 0.02 & 0.01 \\
\hline Lesotho & 0.03 & 46.14 & 2,870 & 848 & 0.00 & 0.00 & 1,492 & 441 & 0.01 & 0.00 \\
\hline Liberia & 0.05 & 42.14 & 2,349 & 577 & 0.00 & 0.00 & & 184 & & 0.00 \\
\hline Madagascar & 0.27 & 44.83 & 2,223 & 633 & 0.02 & 0.01 & 877 & 249 & 0.03 & 0.01 \\
\hline Malawi & 0.19 & 43.17 & 2,683 & 546 & 0.02 & 0.01 & 808 & 165 & 0.02 & 0.01 \\
\hline Mali & 0.19 & 40.28 & 1,798 & 383 & 0.01 & 0.00 & 996 & 212 & 0.03 & 0.01 \\
\hline Mauritania & 0.04 & 46.31 & 5,207 & 1,231 & 0.01 & 0.00 & 1,729 & 409 & 0.01 & 0.00 \\
\hline Moldova & 0.07 & 67.70 & 8,498 & 1,155 & 0.02 & 0.00 & 2,212 & 301 & 0.02 & 0.00 \\
\hline Mongolia & 0.04 & 53.73 & 6,561 & 1,164 & 0.01 & 0.00 & 1,608 & 379 & 0.01 & 0.00 \\
\hline Mozambique & 0.29 & 45.16 & 2,817 & 545 & 0.03 & 0.01 & 1,113 & 215 & 0.04 & 0.01 \\
\hline Myanmar & 0.78 & 57.18 & 6,561 & 1,164 & 0.19 & 0.04 & & 877 & & 0.13 \\
\hline Nepal & 0.40 & 48.53 & 6,561 & 1,164 & 0.10 & 0.02 & 1,321 & 227 & 0.07 & 0.02 \\
\hline Nicaragua & 0.08 & 45.96 & 5,138 & 1,248 & 0.02 & 0.00 & 1,947 & 473 & 0.02 & 0.01 \\
\hline Niger & 0.19 & 40.39 & 1,756 & 329 & 0.01 & 0.00 & 902 & 169 & 0.02 & 0.01 \\
\hline Nigeria & 1.93 & 43.73 & 960 & 377 & 0.07 & 0.04 & 826 & 325 & 0.21 & 0.12 \\
\hline Pakistan & 2.34 & 47.65 & 6,296 & 1,255 & 0.56 & 0.14 & 2,158 & 430 & 0.67 & 0.19 \\
\hline Papua New Guinea & 0.09 & 48.02 & 3,617 & 1,004 & 0.01 & 0.00 & 2,326 & 645 & 0.03 & 0.01 \\
\hline Rwanda & 0.13 & 40.50 & 2,951 & 638 & 0.01 & 0.00 & 976 & 211 & 0.02 & 0.01 \\
\hline Sao Tome and Principe & 0.00 & 44.72 & 3,230 & 773 & 0.00 & 0.00 & 1,317 & 315 & 0.00 & 0.00 \\
\hline Senegal & 0.17 & 43.96 & 4,294 & 1,172 & 0.03 & 0.01 & 1,681 & 459 & 0.04 & 0.01 \\
\hline Sierra Leone & 0.07 & 47.38 & 2,044 & 353 & 0.01 & 0.00 & 734 & 127 & 0.01 & 0.00 \\
\hline Solomon Islands & 0.01 & 46.27 & 3,617 & 1,004 & 0.00 & 0.00 & 1,881 & 774 & 0.00 & 0.00 \\
\hline Somalia & 0.12 & 45.76 & 2,349 & 577 & 0.01 & 0.00 & & 235 & & 0.01 \\
\hline Sudan & 0.54 & 48.64 & 2,349 & 577 & 0.05 & 0.02 & 1,756 & 367 & 0.13 & 0.04 \\
\hline Tajikistan & 0.10 & 46.54 & 2,942 & 298 & 0.01 & 0.00 & 1,380 & 140 & 0.02 & 0.00 \\
\hline Tanzania & 0.57 & 44.79 & 1,246 & 681 & 0.03 & 0.02 & 490 & 268 & 0.04 & 0.03 \\
\hline Timor-Leste & 0.01 & 42.02 & 6,561 & 1,164 & 0.00 & 0.00 & & 457 & & 0.00 \\
\hline Togo & 0.09 & 44.35 & 2,214 & 645 & 0.01 & 0.00 & 926 & 270 & 0.01 & 0.00 \\
\hline Uganda & 0.40 & 38.55 & 2,905 & 725 & 0.04 & 0.01 & 1,030 & 257 & 0.05 & 0.02 \\
\hline Uzbekistan & 0.41 & 51.83 & 6,561 & 1,164 & 0.10 & 0.02 & 1,516 & 552 & 0.08 & 0.04 \\
\hline
\end{tabular}




\begin{tabular}{|c|c|c|c|c|c|c|c|c|c|c|}
\hline Viet Nam & 1.29 & 55.96 & 5,633 & 1,112 & 0.28 & 0.07 & 2,012 & 397 & 0.34 & 0.10 \\
\hline Western Sahara & 0.00 & 52.37 & 2,349 & 577 & 0.00 & 0.00 & & & & \\
\hline Yemen & 0.29 & 40.19 & 1,425 & 537 & 0.02 & 0.01 & 1,293 & 487 & 0.05 & 0.03 \\
\hline Zambia & 0.18 & 42.20 & 2,121 & 789 & 0.01 & 0.01 & 841 & 313 & 0.02 & 0.01 \\
\hline Zimbabwe & 0.21 & 44.71 & 6,863 & 1,465 & 0.05 & 0.01 & 2,607 & 556 & 0.07 & 0.02 \\
\hline
\end{tabular}

